\title{
Toplu Pazarlık Kapsamını Etkileyen Faktörler: Karşılaştırmalı Endüstri ilişkileri Temelinde Türk Endüstri İlişkileri Sisteminin Modernizasyonu
}

\section{Factors Affecting Collective Bargaining Coverage: Modernisation of Turkish Industrial Relations System based on Comparative Industrial Relations}

\author{
Ayhan Görmüş ${ }^{1}$ (1)
}

\section{Öz}

İskandinav ülkelerinde olduğu gibi, yüksek sendikal yoğunluğun toplu pazarlık kapsama oranını yükseltici bir etkisi olmasının yanı sıra, işveren örgütlenme yoğunluğunun yüksek olduğu ülkelerde de, toplu iş sözleşmelerinin genişletilmesi yoluyla, toplu pazarlık kapsama oranı artrılabilmektedir. Ayrıca, toplu pazarlık kapsama oranlarındaki ülkeler arası farklılıklar ve sendikal yoğunluk ile toplu pazarlık kapsamı arasındaki ülke içi farklılıkları tam olarak anlayabilmek için toplu pazarlık düzeylerinin ve bu düzeyler arasındaki koordinasyon derecesinin yanı sıra, genişletme mekanizmasının rolünün incelenmesi gerekmektedir. Ancak, Türkiye örneğinde, toplu pazarlığın kapsamı, değişen yapısı ve toplu pazarlık kapsamını etkileyen faktörlerle ilgili ampirik çalışmaların sınırlı sayıda olduğu görülmektedir. Bu eksikliği gidermek ve literatüre katkı sağlamak için, bu araştırma, Amsterdam Üniversitesi'nin Sendikaların Kurumsal Özellikleri, Ücret Belirleme, Devlet Müdahalesi ve Sosyal Paktları veri merkezinin ve OECD’nin verilerini kullanarak, temel olarak, toplu pazarlık kapsamı ile kapsamı etkileyen faktörler arasındaki ilişkiyi karşılaştırmalı endüstri ilişkileri temelinde analiz etmeyi amaçlamaktadır. Ayrıca sonuç bölümünde, Türk endüstri ilişkileri sisteminin modernizasyonuna yönelik model önerileri tartş̧ımaktadır. Bu çalışma, toplu pazarlık kapsama oranı ile sendikal yoğunluk, toplu pazarlık koordinasyon derecesi ve genişletme mekanizmasının kullanım sıklığı arasında orta düzeyli bir korelasyon, işveren örgütlenme yoğunluğu ve baskın toplu pazarlık düzeyi arasında, yüksek düzeyli bir korelasyon olduğu sonucuna ulaşmıştir.

\section{Anahtar Kelimeler}

Sendikal yoğunluk, İ̧̧veren örgütlenme yoğunluğu, Temsil yetkisi, Genişletme mekanizması

1 Sorumlu Yazar: Ayhan Görmüş (Doç. Dr.), Tekirdağ Namık Kemal Üniversitesi, İktisadi ve İdari Bilimler Fakültesi, Çalışma Ekonomisi ve Endüstri İlişkileri Bölümü, Tekirdağ, Türkiye. E-posta: agormus@nku.edu.tr ORCID: 0000-0002-6175-5381

Attf: Gormus, A. (2020). Toplu pazarlık kapsamını etkileyen faktörler: Karşılaştırmalı endüstri ilişkileri temelinde türk endüstri ilişkileri sisteminin modernizasyonu. Sosyal Siyaset Konferansları Dergisi, 78: 63-109.

https://doi.org/10.26650/jspc.2020.78.0003 


\begin{abstract}
As it is in Scandinavian countries, a high union density ensures the enhancement of collective bargaining coverage rates and also, the collective bargaining coverage can be boosted by the extension mechanism in countries with a high employer organisation density, as it is in France. Additionally, the role of collective bargaining levels, coordination degrees among bargains and the extension mechanism should be examined to fully understand the disparities in collective bargaining coverage rates across countries, and the differences of union density and collective bargaining coverage within the country. However, in the case of Turkey, it has been seen that there is a limited number of empirical studies related to the coverage and changes in the structure of collective bargaining and the factors affecting the collective bargaining coverage. To address this gap and to contribute to the literature, this research, using Amsterdam University database on Institutional Characteristics of Trade Unions, Wage Setting, State Intervention and Social Pacts and OECD's data, mainly aims to analyse the relationship between collective bargaining coverage and the factors affecting collective bargaining coverage based on the comparative industrial relations. Additionally, in the conclusion section, the model proposals for the modernisation of the Turkish industrial relations system are discussed. This study originally concluded that there is a significantly moderate size of correlation relationship between collective bargaining coverage rates and coordination degrees of collective bargaining and the usage frequency of the extension mechanism while having a significantly large size of correlation relationship between collective bargaining coverage rates and the employer organisation density, and a predominant collective bargaining level.
\end{abstract}

\title{
Keywords
}

Union density, Employer organisation density, Representation authority, Extension mechanism. 


\section{Extended Summary}

Employees and employers in democratic countries are organised not only to negotiate wages and employment conditions, but also to protect and develop their interests. The organised representation and the process of the negotiation and making-decision by collective bargaining is a fundamental establishment to regulate the labour market and the main pillar of social dialogue at the national level. Also, rights to organise and collective bargaining are a fundamental right to work determined by the ILO Convention No. 98.

It is well known that, as it is in Scandinavian countries, a high union density ensures the enhancement of collective bargaining coverage rates, and also the collective bargaining coverage can be boosted by the extension mechanism in countries with a high employer organisation density, as it is in France. Besides, the role of collective bargaining levels, coordination degrees between bargains in different levels and the extension mechanism should be investigated to fully understand the disparities in collective bargaining coverage rates across countries, and the differences of union density and collective bargaining coverage within the country.

Although a detailed and comprehensive comparative literature about the developing nature and coverage of collective bargaining has been accumulated, notably in OECD countries, in the case of Turkey, it has been seen that there are limited empirical studies related to the coverage and changing structure of collective bargaining. This literature gap delimitates the access to reliable and updated knowledge about the factors of the collective bargaining coverage in Turkey. In this sense, by using data taken from the Amsterdam University database on ICTWSS and the OECD database, this research mainly aims to analyse the relationship between the collective bargaining coverage and the factors affecting the collective bargaining coverage such as union density, employer organisation density, levels and coordination of the collective bargainings and the extension mechanism based on the comparative industrial relations. Additionally, in the light of findings collected from the study, model proposals for the modernisation of the Turkish industrial relations system will be discussed.

This study originally concluded that there is a significantly moderate size of correlation relationship between collective bargaining coverage rates and coordination degrees of collective bargainings, and the usage frequency of the 
extension mechanism while being of a significantly large size of correlation relationship between collective bargaining coverage rates and the employer organisation density and the predominant collective bargaining level. Also, the other results of the study are the following:

Examining countries with a high collective bargaining coverage, the empirical results and literature imply that high union density, central level of collective bargaining and frequent usage of expansion mechanisms are the factors that increase the collective bargaining coverage. However, the increase in union density needs the existence of a gent system, as it is in the Scandinavian countries, whilst the central level of collective bargaining and the prevalent usage of extension mechanisms depend on a high employer organisation density.

In Turkey, the predominant level of collective bargaining is the workplace and the enterprise levels, while in countries where the collective bargaining coverages are relatively higher than in other countries, collective bargaining is more predominant at the sectoral and national level. Additionally, the negotiation of collective bargaining at the sectoral level is legally impossible in Turkey, however, group collective bargaining, which negotiates at the workplaces and the enterprises in the same industry, may be qualified as the substitution of sectoral collective bargaining.

It is seen that collective bargaining representation criteria in the majority of the countries compared vary according to the domestic dynamics of the countries, and are shaped by having a certain number of members, a legal arrangement, a social agreement, achieving a certain vote threshold in the ballot in which employees participate, and judicial decisions. However, in Turkey, the collective bargaining representation authority is designated by law and consists of a double threshold system: $1 \%$ industry threshold based on the union density in the industry, and the workplace and the enterprise thresholds: $50 \%+1$ for workplaces and $40 \%$ for the enterprises. In practice, the fixation of the collective bargaining representation to the double threshold makes it difficult to achieve a representation authority for newly established unions and leads to a reduction of the collective bargaining coverage.

Although industry and workplaces thresholds which are needed for a collective bargaining representative have been reduced in Turkey after the 
year 2012, collective bargaining coverage rates have still been lower than both trade union density and employer organisation density, and this negative difference continues to increase every year. This reveals that some of the employees, though they are union members, are not covered by collective bargaining, and they face some obstacles related to use their right to organise.

Under the double affiliation principle in Turkey, only signatory bargaining parties and their members can benefit from wages and working conditions determined by collective bargaining. However, it is possible for employees who are not signatory union members to benefit from the collective agreement by paying a solidarity fee.

Finally, although the extension mechanism has been legally regulated since the period of the institutionalisation of industrial relations in Turkey, it does not have a significant effect on the collective bargaining coverage. This is because, until now, it has been rarely used. 


\section{Toplu Pazarlık Kapsamını Etkileyen Faktörler: Karşılaştırmalı Endüstri İlişkileri Temelinde Türk Endüstri İlişkileri Sisteminin Modernizasyonu}

Demokratik ülkelerde çalışanlar ve işverenler, ücret ve istihdam koşullarını müzakere etmenin yanı sıra, çıkarlarını korumak ve geliştirmek için örgütlenmektedirler. Bu örgütlü temsil ve toplu pazarlık yoluyla müzakere etme ve karar alma süreci, hem önemli bir işgücü piyasası düzenleme kurumu, hem de ulusal düzeyde sosyal diyaloğun temel direğidir. Ayrıca "örgütlenme hakkı” ile birlikte, “toplu pazarlık hakkı” Uluslararası Çalışma Örgütü’nün (ILO) 98 sayılı Sözleşmesi ile belirlenen en "temel çalışma hakkıdır" (OECD, 2017: 128). Bu açıdan çalışanlar, kolektif bir hak olan toplu pazarlık haklarını, genellikle bireysel bir hak olan örgütlenme hakkı yoluyla kullandıkları için, örgütlenme hakkı özü itibariyle toplu pazarlık hakkını da içermektedir (Yorgun, 2013: 372). Bununla birlikte, ILO’ya göre çalışanların örgütlenme haklarını kullanmadaki temel amaçlardan biri de, çalışma şartlarını ve koşullarını toplu pazarlık yoluyla belirlemektir. Bu bağlamda, sendikaların toplu pazarlık haklarını yasaklayan ya da engelleyen hükümler, hem ILO'nun 98 sayılı Sözleşmesi'nin 4. maddesine, hem de sendikal faaliyetlerin tam bir özgürlük içinde yürütülmesi ve geliştirilmesi hakkını düzenleyen 87 sayılı Sözleşmesi'nin 3. maddesine aykırı kabul edilmektedir (ILO, 2019: 234).

Ekonomik sistemin alt sistemi olan endüstri ilişkileri sisteminin en önemli unsurlarından biri olan toplu pazarlık, işletme gelirinin sosyal taraflar arasında daha adil bir şekilde paylaşılmasını sağlayan bir mekanizmadır (Zaim, 1997: 317). Bu yönüyle toplu pazarlık mekanizması, işçi ve işverenlerin çalışma hayatının sürekli değişen dinamik ve esnek yapısına hızlı bir şekilde uyum sağlayabilmelerine imkan vermektedir (Görmüş, 2012: 33). Traxler'e (1998) göre, toplu pazarlığın çalışanlar ve işverenler göre değişen farklı fonksiyonları bulunmaktadır. Çalışanlar açısından toplu pazarlığın koruyucu fonksiyonu (düzgün iş koşullarının sağlanması), ses fonksiyonu (çalışanların şikayet ve isteklerini ifade edebilmesi) ve dağıtıcı fonksiyonu (ekonomik süreçlerden pay alma) bulunuyorken, işverenler açısından toplu pazarlık, sosyal barışın korunmasına ve yönetim kontrolünün meşruiyetinin sağlanmasına yardımcı olmaktadır. Devlet açısından ise, serbest toplu pazarlık, devletin yüksek çatışma potansiyeline sahip bir politika alanına müdahale etmek zorunda kalmadan, “müdahale etmeme" ilkesine uymasını sağlamaktadır (Traxler, 1998: 207-208). 
Toplu pazarlık temel olarak, tarafların tespit edilmesi, taleplerin müzakere edilmesi, uyuşmazlık çıkması durumunda uyuşmazlıkların barış̧̧ıl ve mücadeleci araçlarla çözümü ve sonunda ücret ve istihdam koşullarını bir süre için düzenleyen toplu iş sözleşmesinin (TİS) imzalanması ve uygulanması sürecini ifade etmektedir (Zaim, 1997: 315). Bu bağlamda TíS’ler, bir yanda işveren veya örgütleri, diğer yanda çalışanları temsil eden sendikalar arasında imzalanan ücret seviyeleri veya asgari ücretler dahil olmak üzere çalışma koşullarının yanı sıra, çalışma süreleri, yan haklar, eğitim, sağlık ve güvenlik, terfiler, sözleşme türleri, kıdem tazminatı, ikramiyeler, şikayetler gibi diğer birçok konuda düzenleme yapılan iş sözleşmeleridir (Oesingmann, 2016: 59).

Özellikle OECD ülkelerinde, toplu pazarlığın gelişen doğası ve kapsamı hakkında karşılaştırılabilir ayrıntılı ve kapsamlı bir uluslararası literatür oluşmasına rağmen, Türkiye özelinde toplu pazarlığın kapsamı ve değişen yapısına ilişkin yapılan ampirik çalışmaların, oldukça sınırlı olduğu görülmektedir. Bu literatür eksikliği, Türkiye'de toplu pazarlığın kapsamı ve yapısıyla ilgili güvenilir ve güncel bilgiye ulaşımı da sınırlandırmaktadır. Bütün bu eksiklikler ve sinırlılıklar, bu konunun analiz edilmesini ve tartışılmasını daha önemli hale getirmektedir. Bu çerçevede, güncel ve güvenilir bilgi eksikliğini gidermek ve literatüre katk1 yapmak amaciyla yapılan bu çalışmada cevap aranacak sorular şunlardır: Toplu pazarlık kapsamı oranı, sendikal yoğunluk ve işveren örgütlenme yoğunluğu nasıl hesaplanmaktadır? Toplu pazarlık kapsamını etkileyen faktörler nelerdir? $\mathrm{Bu}$ faktörler ile toplu pazarlık kapsamı arasında nasıl bir korelasyon vardır? Türkiye' de toplu pazarlık kapsamı nasıl yükseltilebilir? Türk endüstri ilişkileri sistemi nasıl modernize edilebilir? Bu sorular ve daha fazlasına cevap aramak için bu araştırma temel olarak, ICTWSS ${ }^{1}$ ve Ekonomik Kalkınma ve İşbirliği Örgütü (OECD) verilerini kullanarak, toplu pazarlık kapsamına etki eden sendikal yoğunluk, işveren örgütlenme yoğunluğu, temsil yetkisi kriterleri, toplu pazarlık düzeyi, toplu pazarlıklar arası koordinasyon ve genişletme mekanizması ile toplu pazarlık kapsamı arasındaki ilişkiyi karşılaştırmalı endüstri ilişkileri temelinde analiz etmeyi amaçlamaktadır. Ayrıca, elde edilen bulgular 1şığında Türkiye' de endüstri ilişkilerinin modernizasyonuna yönelik model önerileri tartışılacaktır. Ancak, işçilerden daha farklı bir yapıya ve yasal

1 Visser'in başında olduğu 1960-2018 yılları arasında 55 ülkede Sendikaların Kurumsal Özellikleri, Ücret Belirleme, Devlet Müdahalesi ve Sosyal Paktlarıyla ilgili istatistiki bilgi sağlayan Amsterdam Üniversitesi'ndeki bir veri tabanı. 
mevzuata sahip kamu görevlilerinin örgütlenme ve toplu sözleşme kapsam1, bu çalışmaya dahil edilmemiştir.

Çalışmanın bundan sonraki kısımları, "toplu pazarlık kapsamını etkileyen faktörler", “yöntem", "karşılaştırmalı analiz" ve son olarak elde edilen sonuçların değerlendirildiği ve modernizasyon önerilerinin tartışıldığ "sonuç" bölümlerinden oluşmaktadır.

\section{Toplu Pazarlık Kapsamını Etkileyen Faktörler}

Çalışanların ulusal, bölgesel, sektörel veya şirket düzeylerinde yapılan toplu pazarlıklarla ne ölçüde kapsandığı, endüstri ilişkileri sistemlerin önemli özelliklerinden biridir. Bu yüzden, sendikaların toplu pazarlık sayıları ve toplu pazarlık kapsamındaki çalışan sayısı büyük önem taşımaktadır. Esas olarak toplu pazarlık, "istihdam ilişkisinin asli ve prosedürel şartlarını belirlemek için müzakeresi ve üzerinde anlaşmaya varılmış kurallar dizisinin sürekli olarak uygulanması" anlamına gelen işveren ve çalışan çıkarlarını temsil eden taraflar arasında yürütülen bir karar alma sürecidir (Traxler, 1994: 167). Toplu pazarlık kapsamı ise, ücreti ve/veya istihdam koşulları bir veya daha fazla TİS ile belirlenen işçi sayısını ölçmektedir (ILO, 2018: 9). Bu açıdan, toplu pazarlık kapsamı, ücretlerin ve çalışma koşullarının ne ölçüde toplu pazarlık yoluyla düzenlendiğinin bir göstergesidir (Hayter ve Stoevska, 2009: 2). Bu sayının, ücretleri ve/veya istihdam koşulları genişletme mekanizması yoluyla belirlenen tüm çalışanları içermesi ve yürürlükte olan bütün TİS'lere atıfta bulunması gerekmektedir. Bu bağlamda toplu pazarlık kapsamı, TİS'lerin yapıldığg tarihten bağımsız olarak, yürürlükte olan, en azından bir Tís ile kapsam içine alınmış, tüm çalışanları içermelidir. $\mathrm{Bu}$ nedenle, istatistiki olarak referans döneminden önce imzalanmış, ancak referans döneminde hala yürürlükte olan TİS kapsamında olan işçiler de, toplu pazarlık istatistiklerine dahil edilmelidir. Bu durum TİS’lerin birkaç yıllık süre için imzalandığı yerlerde daha önemlidir (ILO, 2018: 9).

Toplu pazarlık kapsamındaki mutlak işçi sayısına ilişkin istatistikler, bazı amaçlar için oldukça faydalı olsa da, işgücü piyasası yönetiminde toplu pazarlığın rolü veya toplu pazarlıkların çalışma koşullarını ne ölçüde düzenlediğine ilişkin fazla bir şey göstermemektedir. Bu açıdan toplu pazarlık kapsama oranı, toplu pazarlığın işgücü piyasasındaki gerçek öneminin ve çalışan nüfus üzerindeki gerçek etkisinin anlaşılmasını kolaylaştırmaktadır. 
Diğer taraftan, toplu pazarlık kapsamındaki işçi sayısının eğilimini ve kategorilerini, mutlak bir sayıdan ziyade, toplam işçi sayısının oranı olarak yorumlamak çok daha kolaydır. Ayrıca, toplu pazarlık kapsama oranı, bir ülkenin onayladığı işgücü düzenlemelerinin türünü yansıtır ve toplu pazarlık haklarının kullanımına ilişkin bir takım veriler sunar. Bu bağlamda, toplu pazarlık kapsama oranı, ücretli çalışanlar, toplam istihdam, toplu pazarlık hakkına sahip olan çalışanlar vb. tanımlanabilecek uygun işgücünün yüzdesi olarak, en az bir TİS ile kapsanan çalışan sayısını ifade etmektedir (ILO, 2018: 13). Yani, toplu pazarlık kapsamındaki işçi sayısının toplam işçi sayısına bölünerek 100 ile çarpılması halinde, toplu pazarlık kapsamındaki işçilerin oranı elde edilmektedir. Toplu pazarlık kapsama oranının hesaplanmasında, işgücü piyasasının bölümlerini ve/veya hukuki çerçeveyi açıklamak için farklı referans nüfusları kullanılabilmektedir. Ancak, oranların payı ve paydasının aynı referans nüfusuna, aynı referans periyoduna ve alanına ait olması gerekir. Toplu pazarlık kapsamı, bir veya daha fazla TİS kapsamında olan ücretli çalışanlar olarak ölçülüyorsa, payda olarak toplam ücretli çalışan sayısı kullanılmalıdır. Ancak toplu pazarlık kapsamı, bir veya daha fazla TİS kapsamına giren istihdam edilenler (ücretli çalışanlar ve kendi hesabına çalışanlar) olarak ölçülüyorsa, bu durumda, paydanın toplam istihdam olması gerekecektir. Ayrıca, toplu pazarlık hakkı kapsamında hukuki çerçeveyi dikkate alarak da toplu pazarlık kapsama oranını hesaplamak mümkündür. Bazı işçi gruplarının toplu pazarlık hakkına sahip olmaması durumunda, bu gruplar, referans grubunu fiili TİS kapsamına girebilecek çalışanlarla sınırlandırmak için, toplu pazarlık kapsama oranının paydasından çıkarılabilir. Bu şekilde hesaplanan toplu pazarlık kapsama oranı, potansiyel olarak kapsanabilecek olanlara göre, çok daha doğru bir sonuç verecektir (ILO, 2018: 9-10). Diğer taraftan, istihdamdaki ücretliler için toplu pazarlık kapsama oranlarının hesaplanmasında standart bir uygulama olmasına rağmen, kayıt dışı istihdamın yüksek olduğu ülkelerde, resmi çalışan kategorisi toplam istihdama kıyasla, daha düşük olabilir ve yüksek toplu pazarlık kapsama oranları, işgücü piyasalarında toplu pazarlığın önemiyle ilgili çarpıtılmış bir tablo sunabilir. $\mathrm{Bu}$ yüzden, toplam istihdama kayıt dışı çalışanlar ilave edilerek, bu hata düzeltilebilir ve daha doğru bir sonuca ulaşılabilir (Visser vd., 2017: 3).

Bu çalışmanın amaçlarından biri “Türkiye'de düşük olan toplu pazarlık kapsamının nasıl yükseltilebileceği??” sorusuna cevap aramaktır. İskandinav ülkelerinde olduğu gibi, yüksek sendikal yoğunluk oranının toplu pazarlık 
kapsama oranını yükseltici bir etkisi olmasının yanı sıra, işveren örgütlenme yoğunluğunun yüksek olduğu ülkelerde de, TİS’lerin genişletilmesi yoluyla, toplu pazarlık kapsama oranının yükseltildiği bilinmektedir (Oesingmann, 2016: 62-63). Diğer taraftan, toplu pazarlık kapsama oranlarındaki ülkeler arası farklılıklar ve toplu pazarlık kapsamı ile sendikal yoğunluk arasındaki ülke içindeki farklılıkları tam olarak anlayabilmek için toplu pazarlık düzeylerinin ve farklı düzeylerde yapılan toplu pazarlıklar arasındaki koordinasyon derecesinin yanı sıra, genişletme mekanizmasının rolünün açıklanması gerekmektedir (Traxler, 1994: 174). Bu açıdan, çalışmanın geri kalan kısımlarında toplu pazarlık kapsamına etki eden sendikal yoğunluk ve işveren örgütlenme yoğunluğu, toplu pazarlık temsil yetkisi, toplu pazarlık düzeyleri ve düzeyler arası koordinasyonunun yanı sıra, genişletme mekanizması açısından, Türkiye'ye model olabilecek ülkelerin endüstri ilişkileri sistemleri karşılaştırmalı olarak incelenecektir. Ancak analize başlamadan önce, çalışmada kullanılacak karşılaştırmalı yöntem, veri ve analitik teknik açıklanacaktır.

\section{Yöntem}

\section{Karşılaştırmalı Endüstri İlişsilerinde Yöntem ve Veri}

Küreselleşme ile birlikte ülkeler arasındaki ekonomik bağların giderek artması, farklı ülkelerdeki endüstri ilişkileri ve çalışma ilişkileri uygulamalarıyla ilgili bilgiye daha fazla ihtiyaç duyulmasına yol açmış ve bu durum son y1llarda karşılaştırmalı endüstri ilişkilerine olan ilgiyi artırmıştır (Bamber vd., 2004: 3-4). Aslında, endüstri ilişkilerinde uluslararası karşılaştırmalı araştırmalar yapmak, güçlü bir gelenektir. Kochan'a (1998) göre, endüstri ilişkilerine uluslararası açıdan bakmak, endüstri ilişkilerinde kültür, ideoloji ve kurumsal yapılar gibi kritik değişkenler üzerinden mevcut karşılaştırma alanını genişletmekte ve yeni teorik görüşler ve açıklamalar geliştirmek için ihtiyaç duyulan sistematik varyasyonları keşfetme şansını artırmaktadır. Strauss ise, karşılaştırmalı endüstri ilişkilerini sadece tek bir ülkede değil, her yerde geçerli olan ilkelerin geliştirilmesini teşvik eden bir alan olarak görmektedir (Whitfield vd., 1999: 971). Diğer taraftan, Blanpain'e (1982) göre, endüstri ilişkileri sistemlerinin karşılaştırılması, farklı ulusların endüstri ilişkileri sistemlerinden elde edilen bulguların ve hipotezlerin test edilmesi, genelleştirici bilgiye ulaşılması ve teori oluşturmaya katkı sağlaması 
bakımından oldukça faydalıdır. Ancak, karşılaştırmalı araştırmaların en önemli sorunlarından biri, neyin nasıl karşılaştırılacağıdır. Bazı araştırmacılara göre, karşılaştırmalı endüstri ilişkileri araştırması, geleneksel olarak ulusal sistemleri temel analiz birimi olarak ele almalı ve endüstri ilişkilerinin karşılaştırmalı tipolojilerini oluştururken, makro-kurumsal özelliklere odaklanmalıdır (Locke vd., 1995: 140; Görmüş, 2018: 4). Bu yaklaşım, bir ülkenin endüstri ilişkilerini içinde geliştiği tarih, kültür, sosyo-ekonomik yapı ve siyasal düzlem içerisinde inceleme imkânı sağmaktadır (Dereli, 2009: 6). Diğer araştırmacılara göre ise, karşılaştırmalı endüstri ilişkileri sendikal yoğunluk, toplu pazarlık kapsamı, pazarlığın merkezileşmesi veya düzeyi, toplu pazarlıklar arası koordinasyon, işçi katılımının derecesi ve devletin ücret müzakerelerine katılım derecesi gibi ölçülebilir kurumsal değişkenleri incelemelidir (Black, 2005: 1137; Görmüş, 2018: 4). Bu yaklaşım ise, endüstri ilişkileri sistemlerinin kurumsal yapılarının işleyişini farklı ülkelere göre değerlendirme imkânı vermektedir (Dereli, 2009: 7-8). Ayrıca uluslararası karşılaştırmalar, ulusal endüstri ilişkileri sistemlerinin benzerlik ve farklılıkların ortaya çıkarılması ve açıklanması bakımından son derece önemlidir (Blanpain, 1982: 17). Ancak karşılaştırmalı endüstri ilişkilerinde karşılaşılan en temel zorluk, endüstri ilişkileri kurumlarının ülkeler arası çeşitliliğini açıklayabilmektir (Black, 2005: 1137). Bu bağlamda uluslararası karşılaştırmalı araştırmalarda, ulusal ve uluslararası istatistiki veriler, örnek olay çalışmaları (genellikle ülkeler arasında eşleştirme yapılır), tarihi belgeler ve anket bilgileri kullanılmaktadır (Whitfield vd., 1999: 971).

$\mathrm{Bu}$ çalışmanın yöntemi temel olarak, toplu pazarlık yapılarının kurumsal işleyişini ülkelere göre incelemek için, toplu pazarlık kapsama oranı ile toplu pazarlık kapsamına etki eden sendikal yoğunluk, işveren örgütlenme yoğunluğu, temsil yetkisi kriterleri, baskın toplu pazarlık düzeyi, toplu pazarlıklar arası koordinasyon derecesi ve genişletme mekanizması arasındaki ilişkilerin karşılaştırmalı endüstri ilişkileri temelinde incelenmesine dayanmaktadır. Bu doğrultuda, çalışmada kullanılan 50 ülkenin toplu pazarlık kapsama oranı, sendikal yoğunluk ve işveren örgütlenme yoğunluğu verileri ICTWSS'den, baskın toplu pazarlık düzeyi ve toplu pazarlık koordinasyon derecesi ve genişletme mekanizmasının kullanım sıklığı verileri OECD’den ve Türkiye'ye ait toplu pazarlık ve sendikal istatistikler ise, Aile, Çalışma ve Sosyal Hizmetler Bakanlığı'ndan (AÇSHB) alınmıştır. 


\section{Analitik Teknik}

Korelasyon analizi, iki değişken arasındaki doğrusal ilişkiyi veya bir değişkenin iki ya da daha fazla değişkenle olan ilişsisini test etmek, varsa bu ilişkinin derecesini ölçmek için kullanılan istatistiksel bir yöntemdir. Korelasyon analizi, bağımsız değişken (X) değiştiğinde, bağımlı değişkeninin (Y) ne yönde değişeceğini görmeyi amaçlamaktadır. Analiz sonucunda değişkenler arasında doğrusal ilişkinin olup olmadığı ve varsa, ilişkinin derecesi korelasyon katsayısı (r) ile ölçülmekte ve $\mathrm{r}-1$ ile $1(-1 \leq \mathrm{r} \leq+1)$ arasında bir değer almaktadır (Sungur, 2014: 115). Korelasyon katsayısının " 0,00 ile 0,25 ” arasında bir değer alması iki değişken arasında "çok zayıf” bir ilişki; "0,26 ile 0,49” arasında bir değer alması "zayıf” bir ilişki; "0,50 ile 0,69" arasında bir değer alması "orta düzeyde” bir ilişki; “ 0,70 ile 0,89 ” arasında bir değer alması "yüksek” bir ilişki; “0,90 ile 1,00” arasında bir değer alması ise, "çok yüksek” bir ilişki olduğunu göstermektedir. Korelasyon katsayısının negatif değer alması, iki değişken arasında ters orantılı bir ilişki olduğunu, pozitif değer alması ise, iki değişken arasında doğru orantılı bir ilişki olduğunu ifade etmektedir. Ayrıca, korelasyon katsayısının 0,05'ten küçük olması $(\mathrm{p}<0,05)$, değişkenler arasında anlamlı bir ilişki olduğu şeklinde yorumlanmaktadır.

Korelasyon analizinde, kullanılan değişkenlerin sürekli olmaları ve normal dağılım gösterme varsayımlarını karşılaması gerekmektedir. Bu çalışmada kullanılan değişkenlere yapılan çan eğrisi ve Kolmogorov-Smirnov ve Shapiro-Wilk testlerinden toplu pazarlık kapsama oranı değişkeninin normal dağılım varsayımına uymadığı, yani parametrik olmadığı görülmüştür. $\mathrm{Bu}$ yüzden, bu analizde non-parametrik değişkenlerin analizinde kullanılan Spearman korelasyon katsayısı kullanılmıştır (Sungur, 2014: 117).

\section{Karşılaştırmalı Analiz}

\section{Sendikal Yoğunluk ve İşveren Örgütlenme Yoğunluğu: Kavram ve Ölçüm}

Sendikal yoğunluk, çoğunlukla çalışanların örgütlenme derecesinin bir göstergesi olarak kullanılmaktadır. Sendikal güç açısından, sendikalı işçi sayısı, endüstri ilişkilerinin temel göstergelerinden biridir ve sendikal yoğunluğun hesaplanmasında sıklıkla kullanılmaktadır (Hayter ve Stoevska, 2009: 2). Bu açıdan, sendikal yoğunluk, bir ülkenin endüstri ilişkileri sisteminin temel karakteristik göstergelerinden biridir (Traxler, 1994: 167). 
Ancak, sendikal yoğunluk sadece sendikalaşma kapsamını ölçmekle birlikte, sendikaların pazarlık gücü ya da etkisiyle ilgili sınırlı bir bilgi vermektedir (Hayter ve Stoevska, 2009: 2). Eurofound'un (2019) tanımına göre, sendika üyesi ücretli ve maaşlı çalışanların, bir ekonomideki toplam ücretli ve maaşlı çalışanlara oranı sendikal yoğunluk olarak ifade edilmektedir. Ancak sendikal yoğunluğun hesaplanmasında ve sendika üye sayılarının tespitinde, bazı ülkelerde kaynak çeşitliliği (resmi idari veriler, sendikalar tarafından sağlanan veriler, anket verileri vb.) bulunurken, bazı ülkelerde ise, güvenilir verilere ulaşmak oldukça zordur (Eurofound, 2009).

Sendikal yoğunluk brüt ve net olmak üzere iki şekilde hesaplanabilmektedir. Brüt yoğunluk, istihdamdaki tüm ücretli ve maaşlı çalışanların veya işsizleri de içeren sivil işgücünün, işsizler, öğrenciler ve emekli çalışanlar da dahil, toplam sendika üyelerine oranı olarak tanımlanmaktadır. Bu geniş tanım, işgücü içindeki sendikal temsilin resmini daha gerçekçi bir şekilde gösterebilir, ancak bu hesaplama yönteminde örneğin sendikalı emeklilerin sayısı ne kadar yüksek olursa, sendikal yoğunluk oranı da o kadar hatalı çıkacaktır. Bu hatanın düzeltilmesi için işsizler, öğrenciler ve emekli çalışanlar çıkarılarak, aktif ücretli ve maaşlı çalışan sayısının sendika üyesi çalışan sayısına oranlanması ile net sendikal yoğunluk hesaplanabilir. Bu yöntem, işçi sendikalarının işgücündeki temsiliyet oranlarına ilişkin daha doğru bir tahmin sonucunu vermektedir (Lesch, 2004: 12).

İşverenler ve işveren örgütleri toplu pazarlığın bir diğer önemli aktörleridir. Ancak çalışanlardan farklı olarak, işverenler tek başlarına bir toplu pazarlığın tarafi olabilecekleri gibi, toplu pazarlıkta bir işveren örgütü tarafından da temsil edilebilmektedirler. Sendikal yoğunlukta olduğu gibi, işverenlerin örgütlenme yoğunluğu da, işveren örgütüne üye işyerlerinde çalışanların toplam istihdam içindeki ücretli ve maaşlı çalışanlara oranını ifade etmektedir (Visser, 2019).

\section{Toplu Pazarlık Kapsamının Sendikal Yoğunluk ve İşveren Örgütlenme Yoğunluğu ile Karşılaştırmalı Analizi}

Toplu pazarlık kapsamı endüstri ilişkileri sisteminin belirli özelliklerinin bir fonksiyonudur. Örneğin, merkezi düzeyli toplu pazarlıklar yüksek kapsama oranları ile ilişkilendirilirken, adem-i merkezi toplu pazarlıklar görece daha düşük kapsama oranları ile ilişkilendirilme eğilimindedir. Ayrıca, toplu pazarlıkla belirlenen ücret ve çalışma koşullarının genişletme mekanizması yoluyla toplu pazarlığa taraf olmayan işyerlerine ve çalışanlara uygulanması 
da toplu pazarlık kapsama oranlarını yükseltmektedir (Hayter ve Stoevska, 2009: 2). Ancak etkili bir toplu pazarlık yapabilirse, sendikaların üye sayılarının artacağı, yani çalışanların sendikaya üye olma motivasyonun imzalanan TíS'lere bağlı olduğu, düşünülmektedir (Scheuer, 1997: 65). Bu açıdan, bir ülkede toplu pazarlık kapsama oranının yüksek olması, İskandinav ülkelerinde olduğu gibi, söz konusu ülkede toplu pazarlık hakkını engelleyen ya da sınırlayan bir takım düzenlemelerin olmadığı ve toplu pazarlık kapsamının, görece daha düşük olduğu ülkelere kıyasla, sosyal adaletin ve çalışma barışının nispi olarak daha ileri düzeyde olduğunu göstermektedir (Yorgun, 2013: 372).

Önceden, sendikal yoğunluk işgücü piyasasında sendikal gücü ifade eden toplu pazarlık kapsamının bir göstergesi olarak görülmekteydi. Ancak daha sonra, özellikle bazı ülkelerde toplu pazarlık kapsamının sendikal yoğunluktan çok daha yüksek olduğu görülünce, sendika üyeliği ve toplu pazarlık kapsamının her zaman denk gelmeyen iki farklı değişken olduğu görüşü giderek yaygınlık kazanmıştır. Çünkü sendikal yoğunluk ve toplu pazarlık kapsamı, işyerindeki kolektivizmin (kısmen bağımsız) iki temel boyutunu oluşturmasına rağmen, çalışanlar bazen TİS'den sendikaya üye olmadan serbestçe yararlanabilmektedirler. Ancak bu durumun tersi de mümkündür. Yani, sendika üyeleri toplu pazarlık kapsamına girmeyen işyerlerinde de çalışabilmektedirler. Bunun böyle olmaması gerektiğini belirten bir kanun yoktur, ancak bu durum, "sendika toplu pazarlık yapamıyorsa, çalışanların neden sendikaya üye olacağı?” sorusunu akla getirmektedir (Scheuer, 1997: 66-67). Çünkü ücret ve çalışma koşulları üzerinde toplu pazarlık yapmak, çoğu sendikanın en temel faaliyet alanıdır. Dolayısıyla, ne kadar fazla işçi sendikalaşırsa, o kadar fazla işçinin toplu pazarlık kapsamına girmesi beklenir, ancak bu ilişki her koşulda tam anlamıyla geçerli değildir.

Grafik 1'deki ülkeler toplu pazarlık kapsama oranları açısından yüksekten düşüğe doğru sıralanmıştır. Grafik 1 incelendiğinde, ülkeler arasında genel olarak, yüksek sendikal yoğunluğun, tanımı gereği, yüksek bir toplu pazarlık kapsama oranına yol açtığı, ancak düşük sendikal yoğunluğun, her ülkede düşük toplu pazarlık kapsama oranına neden olmadığı görülmektedir. Örneğin, güncel sendikal yoğunluk Fransa'da \%8,8 ve İspanya \%13,6 iken, toplu pazarlık kapsama oranları sirasıyla \%94 ve \%68'dir. Ayrıca toplu pazarlık kapsama oranı, sendikal yoğunluk oranından daha düşük olan, Türkiye gibi, ülkelerin de olduğu dikkat çekmektedir (Visser vd., 2017: 3). 


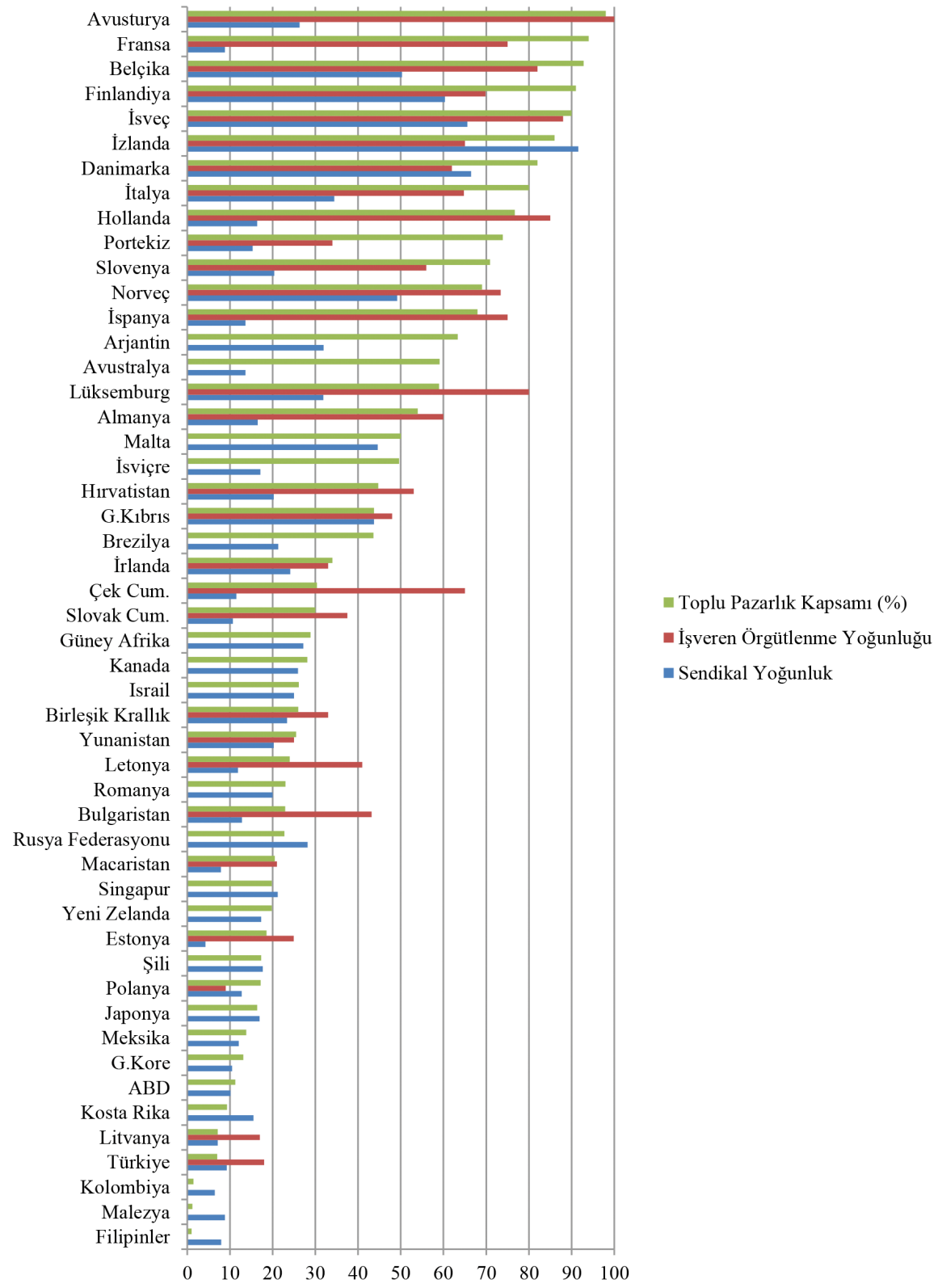

Grafik 1. Ülkelerin toplu pazarlık kapsama oranı ve örgütlenme yoğunluğu verileri

Kaynak: Visser, (2019), ICTWSS Database Version 6.1

Not: 2013-2018 yıllarından ülkelere ait en güncel yıl verileri kullanılmıştır. Toplu pazarlık kapsama oranı, pazarlık hakkına sahip tüm ücretli ve maaşlı istihdam edilenlerin geçerli bir TíS kapsamındaki çalışanlara oranını; Sendikal yoğunluk, net sendika üyelilerinin istihdamdaki toplam ücretli ve maaşlı çalışanlara oranını; İ̧sveren örgütlenme yoğunluğu ise, işveren örgütlerine üye işyerlerinde çalışanların, istihdamdaki toplam ücretli ve maaşlı çalışanlara oranını ifade etmektedir (Visser, 2019). 
Grafik 1'e detaylı bakıldığında, ülkelerinin toplu pazarlık kapsama oranı ile sendikal yoğunluk ilişkisi açısından kabaca dört farklı gruba ayrıldığ 1 görülmektedir:

- İlk grupta İzlanda, Belçika, İsveç, Finlandiya, Danimarka ve Norveç gibi, görece hem sendikal yoğunluk ve işveren örgütlenme yoğunluğunun, hem de toplu pazarlık kapsamının yüksek olduğu ülkeler yer almaktadır. Bu ülkelerde, sendikalar tarafindan kontrol edilen ve devlet tarafindan sübvanse edilen ve gönüllü üyelik temelli bir işsizlik sigortası fonu olan "Gent Sistemi’ne” (Ghent system) bağlı olarak, sendikal yoğunluk yüksek bir oranda gerçekleşmektedir (Høgedahl ve Kongshøj, 2017: 366). Ayrıca sendikal yoğunluğun ve işveren örgütlenme yoğunluğunun birlikte yüksek olması, yüksek bir toplu pazarlık kapsamına ulaşılmasını sağlamaktadır (Oesingmann, 2016: 62).

- Fransa,İspanya, İsviçre, Portekiz, Hollanda, Almanya, Avusturya, Slovenya, Lüksemburg, Arjantin ve İtalya'nın yer aldığı ikinci grup ülkelerde ise, sendikal yoğunluk, diğer ülkelere kıyasla, görece daha düşük olmasına rağmen, işveren örgütlenme yoğunluğu ve toplu pazarlık kapsama oranının görece daha yüksek olduğu gözlenmektedir. Bu ülkeler içerisinde TíS Şartları İtalya ve İspanya'da otomatik olarak, Fransa gibi bazılarında ise, yarı otomatik (quasi-automatic) olarak, genişletme mekanizması yoluyla toplu pazarlık tarafi olmayan işverenlerin çalışanlarına da uygulanmaktadır (OECD, 2017: 141). Bu yüzden, bu ülkelerdeki düşük sendikal yoğunluğa rağmen (sırasıyla \%34,4; \%13,6 ve \%8,8), oldukça yüksek toplu pazarlık kapsama oranları (sırasıyla \%80; \%68 ve \%94) dikkat çekmektedir. Ancak bu ülkelerde işverenlerin örgütlenme yoğunluğu göreceli olarak yüksektir ve bu da toplu pazarlık kapsamını artıran bir etki oluşturmaktadır (Oesingmann, 2016: 62). Buna göre, işverenlerin örgütlenme yoğunluğu örneğin İtalya'da 2012'de \%64,8; İspanya'da 2013'de \%75 ve Fransa'da 2012'de \%75 olarak ölçülmüştür (Visser, 2019).

- Üçüncü grupta yer alan ABD, Kanada, Birleşik Krallık, Güney Kore, Meksika, Polonya, Estonya, Macaristan, Bulgaristan, Romanya ve İsrail gibi ülkelerde, görece hem sendikal yoğunluk, hem de toplu pazarlık kapsama oranı düşük olmasına rağmen, toplu pazarlık kapsama oranının sendikal yoğunluktan kısmen daha yüksek olduğu görülmektedir. Bunun nedeni, Güney Kore ve Şili hariç, diğer ülkelerde, zorunlu olmamasına rağmen, TİS şartlarının taraf sendika üyesi olsun ya da olmasın işyerinde 
çalışan bütün işçilere uygulanmasıdır (OECD, 2017: 141).

- Son olarak Filipinler, Malezya, Kolombiya, Türkiye, Kosta Rika, Japonya, Şili, Singapur ve Rusya Federasyonu'nda sendikal yoğunluk ve toplu pazarlık kapsama oranları görece düşük olmakla birlikte, toplu pazarlık kapsama oranının sendikal yoğunluktan kısmen daha düşük olduğu görülmektedir. Çalışanların bir sendikaya üye olmaktaki en temel beklentisi bir toplu pazarlık kapsamına girmek olmasına rağmen, bu ülkelerdeki sendikalı çalışanlardan bir kısmının toplu pazarlık kapsamına giremediği görülmektedir. Visser ve arkadaşlarına (2017) göre, bu farklılığın dört temel açıklaması olabilir. İlk olarak, sendika üyelik verilerindeki idari gecikmelerin, raporlama hatalarının ve farklı kaynakların neden olduğu ölçüm hataları gerçek resmi tam olarak yansıtmayabilir. İkincisi, sendika üyeliği toplu pazarlık dışındaki yöntemlerin istihdam şart ve koşullarının belirlenmesinde rol oynadığı kamu hizmetlerinde (örneğin kamu hizmeti danışma organları) yoğunlaşabilir. Üçüncüsü, sendikalar birincil rollerinin toplu pazarlık değil de, siyasi lobi faaliyeti ve sosyal güvenlik sistemi yönetimi olduğunu düşünebilirler. Son olarak, işverenler toplu pazarlığa direnç gösterebilir ve sendikalar, toplu pazarlık biriminde üyeleri olmasına rağmen, toplu pazarlık amacıyla tanınma ya da temsil yetkisi için gereken çoğunluğa ulaşmakta zorlanabilirler (Visser vd., 2017: 3-4).

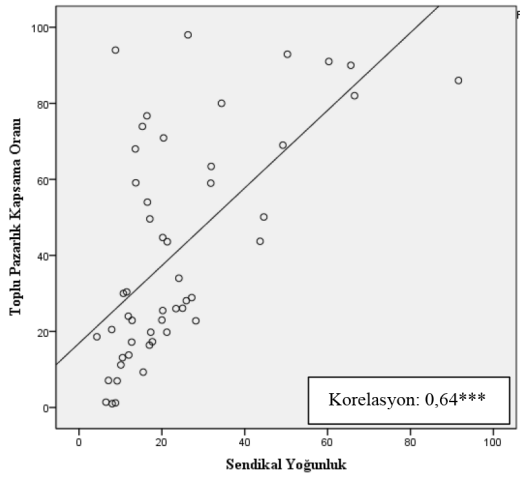

Grafik 2. Toplu pazarlık kapsama oranı ile sendikal yoğunluk arasındaki ilişki

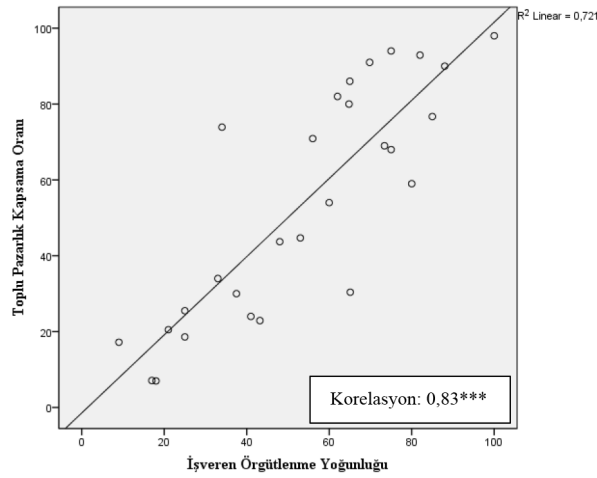

Grafik 3. Toplu pazarlık kapsama oranı ile işveren örgütlenme yoğunluğu arasındaki ilişki

*** 0,001 düzeyinde istatistiksel olarak anlaml

Kaynak: Visser, (2019), ICTWSS Database Version 6.1

Not: 2013-2018 yıllarından ülkelere ait en güncel yıl verileri kullanılmıştır. 
Sendikal yoğunluk ile toplu pazarlık kapsamı arasında yakın bir ilişki olduğu düşünülebilir. Çünkü sendikalar temelde toplu pazarlık yoluyla üyelerinin hak ve çıkarlarını koruyup geliştirebilmek için örgütlenmekte ve üye sayılarını artırmaktadır (Kutal, 2014: 15). Sendikal yoğunluk ile toplu pazarlık kapsamı arasındaki ilişkiyi daha anlayabilmek için Grafik 1'de yer alan ülkelerinin sendikal yoğunluk ve toplu pazarlık kapsama oranları arasındaki korelasyon, Grafik 2'de gösterilmiştir. Grafiğe göre, sendikal yoğunluk ile toplu pazarlık kapsama oranı arasında doğrusal yönde orta düzeyli anlamlı $(r=0,64 ; p<0,001)$ bir korelasyon gözlenmektedir. Bu sonuç, OECD'nin (2017) raporunda, bazı OECD ülkeleri örnekleminde sendikal yoğunluk ile toplu pazarlık kapsamı arasında bulduğu korelasyon sonucunu $(\mathrm{r}=0,64)$ teyit etmektedir. Traxler'in, (1994) 17 OECD ülkesinin 1990 y1lı sendikal yoğunluk ve toplu pazarlık kapsamı oranlarını kullanarak yaptığ 1 çalı̧̧masında ise, “yüksek sendikal yoğunluk, zorunlu olarak yüksek bir toplu pazarlık kapsama oranı ile ilişkilendirilirken, bu iki oran arasında $(r=0,41)$ zayıf bir korelasyon olduğu sonucuna ulaşılmıştır (Traxler, 1994: 174). OECD’ye (2017) göre, çoğu gelişmiş ülkede genişletme mekanizmaları ile sendika üyesi olmayanlar da toplu pazarlık kapsamına alındıklarından, toplu pazarlık kapsama oranı sendikal yoğunluktan önemli ölçüde daha yüksekken, bazı ülkelerde de sendikal yoğunluğun altında bir toplu pazarlık kapsamı gerçekleşmektedir. Bu durum sendikal yoğunluk ile toplu pazarlık kapsamı arasındaki ilişkiyi zayıflatmaktadır (OECD, 2017: 137). Ancak bu sonuç, sendikal yoğunluk ile toplu pazarlık kapsamı arasında doğru orantılı bir ilişki olduğu gerçeğini değiştirmez.

Grafik 3'te işveren örgütlenme yoğunluğu ve toplu pazarlık kapsama oranları arasındaki korelasyon gösterilmektedir. Grafik 1'deki ülkelerin işveren örgütlenme yoğunluğu ile toplu pazarlık kapsama oranı arasında doğrusal yönde yüksek düzeyli anlamlı $(\mathrm{r}=0,83 ; \mathrm{p}<0,001)$ bir korelasyon görülmektedir. OECD'nin (2017) raporundaki $(\mathrm{r}=0,90)$ bulguyu teyit eden bu sonuç, toplu pazarlık kapsamanın, işveren örgütlenme yoğunluğu ile daha fazla ilişkili olduğunu ortaya koymaktadır.

\section{Türkiye’de Toplu Pazarlık Kapsamı ve Sendikal Yoğunluk}

Türkiye' de sendikal işkolu istatistikleri, yasa gereği, 1984'ten beri bugünkü adı ile AÇSHB tarafindan resmi gazetede yayımlanmaktadır. Bu çalışmada, 
2012'de yürürlüğe giren 6356 sayılı Sendikalar ve Toplu İş Sözleşmesi Kanunu (STİSK) ile 2012 yılından itibaren sendikal işkolu istatistiklerinin hesaplanmasında yeni yöntem ve veri serisine geçildiği için, 2013 yılı sonrası veriler kullanılmıştır.

Tablo 1'de AÇSHB tarafindan yayımlanan Türkiye'nin 2013 yılı sonrası sendikal yoğunluk ve toplu pazarlık kapsamı oranları ve bu oranların hesaplanmasında kullanılan işçi sayıları gösterilmiştir. Tablodaki toplam işçi sayılarında, yasa gereği, Sosyal Güvenlik Kurumu'na (SGK) bildirimleri yapılan işçi sayısı baz alınmıştır. Tablo 2'de ise, OECD’nin Türkiye için yayınladığı sendikal yoğunluk ve toplu pazarlık kapsamı istatistikleri gösterilmektedir.

Tablo 1

Türkiye'de Toplu Pazarlık Kapsamı ve Sendikal Yoğunluk Verileri

\begin{tabular}{|c|c|c|c|c|c|c|c|}
\hline & 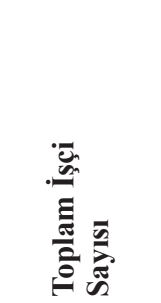 &  & 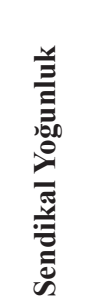 & 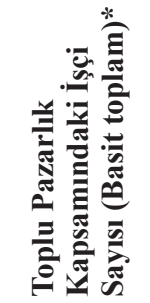 & 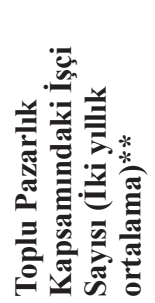 & 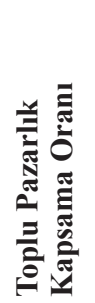 & 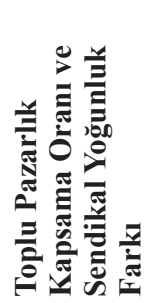 \\
\hline 2013 & 10.881 .618 & 1.001 .671 & 9,21 & 889.601 & 810.102 & 7,44 & $-1,76$ \\
\hline 2014 & 11.600 .554 & 1.096 .540 & 9,45 & 1.031 .352 & 960.477 & 8,28 & $-1,17$ \\
\hline 2015 & 12.180 .945 & 1.297 .464 & 10,65 & 1.029 .977 & 1.030 .665 & 8,46 & $-2,19$ \\
\hline 2016 & 12.663 .783 & 1.514 .053 & 11,96 & 1.142 .791 & 1.086 .384 & 8,58 & $-3,38$ \\
\hline 2017 & 12.699 .769 & 1.546 .565 & 12,18 & 1.282 .525 & 1.212 .658 & 9,55 & $-2,63$ \\
\hline 2018 & 13.884 .196 & 1.714 .397 & 12,38 & - & - & - & - \\
\hline 2019 & 13.411 .983 & 1.859 .038 & 13,86 & - & - & - & - \\
\hline 2020 & 13.856 .801 & 1.917 .893 & 13,84 & - & - & - & - \\
\hline $\begin{array}{l}\text { 2013-Son Veri } \\
\text { Dönemi Farkı }\end{array}$ & 1.818 .151 & 916.222 & 5 & 392.924 & 402.556 & 2,11 & $-0,87$ \\
\hline
\end{tabular}

Kaynaklar: AÇSHB, Sendikal İstatistikler, Ocak 2013-Ocak 2020; AÇSHB, Yıllar İtibarıyla İmzalanan Toplu İş Sözleşmeleri 1984-2017.

* İşyerinde çalışan toplam işçi sayısıdır. TİS kapsamındaki işçi sayısı TİS'ler 2 yıllık imzalandığı için 2 yılın toplamı olarak yazar tarafından hesaplanmıştır.

** İki yıllık basit toplamlar, özellikle TİS'lerinin sarkması nedeniyle, ardışık olarak toplanıp ikiye bölünerek yazar tarafından hesaplanmıştır (Yöntem için bkz. Çelik ve Lordoğlu, 2006: 19). 
Tablo 2

OECD’nin Türkiye'de Toplu Pazarlık Kapsamı ve Sendikal Yoğunluk Verileri

\begin{tabular}{cccccc}
\hline & $\begin{array}{c}\text { Toplam İsçi } \\
\text { Sayısı (000) }\end{array}$ & $\begin{array}{c}\text { Sendikalı } \\
\text { İşçi Sayısı } \\
\mathbf{( 0 0 0 )}\end{array}$ & $\begin{array}{c}\text { Sendikal } \\
\text { Yoğunluk }\end{array}$ & $\begin{array}{c}\text { Toplu } \\
\text { Pazarlık } \\
\text { Kapsama } \\
\text { Oranı }\end{array}$ & $\begin{array}{c}\text { Toplu Pazarlık } \\
\text { Kapsama Oranı ve } \\
\text { Sendikal Yoğunluk } \\
\text { Farkı }\end{array}$ \\
\hline $\mathbf{2 0 1 3}$ & 16.345 & 1.032 & 6,31 & 5,4 & $-0,91$ \\
$\mathbf{2 0 1 4}$ & 17.122 & 1.189 & 6,94 & 6,5 & $-0,44$ \\
$\mathbf{2 0 1 5}$ & 17.860 & 1.429 & 8,00 & 6,6 & $-1,40$ \\
$\mathbf{2 0 1 6}$ & 18.374 & 1.500 & 8,16 & 6,7 & $-1,46$ \\
$\mathbf{2 0 1 7}$ & 18.958 & 1.624 & 8,57 & 7,0 & $-1,57$ \\
$\mathbf{2 0 1 8}$ & 19.523 & 1.802 & 9,23 & - & - \\
$\mathbf{2 0 1 3 - S o n ~ V e r i ~}$ & 3.178 & 770 & 3 & 1,6 & $-0,66$ \\
Dönemi Farkı & & & 3 & & \\
\hline
\end{tabular}

Kaynak: OECD Stat, Trade Unions and Collective Bargaining 2013-2018, https://stats.oecd.org/

Tablo 1 ve 2 karşılaştırıldığında, sendikalı işçi sayısı açısından her iki tablo arasında çok önemli sapmalar bulunmazken, toplam işçi sayısı bakımından önemli farklılıkların olduğu gözlenmektedir. Bu fark, OECD'nin toplam işçi sayısı tespitinde kayıt dışı çalışanları da hesaba katarak, geniş kapsamlı bir ücretli ve maaşlı çalışan tanımı kullanmasından kaynaklanmaktadır. Dolayısıyla, OECD'nin tespit ettiği sendikal yoğunluk oranları, AÇSHB'nin belirlediği oranlardan daha düşük gözükmektedir. Aynı fark, benzer nedenle, toplu pazarlık kapsamı oranında da göze çarpmaktadır. Diğer taraftan, her iki tabloda gerek toplam işçi sayısının, gerekse sendikalı işçi sayısının yıllar itibariyle artış gösterdiği görülmektedir. Bu çerçevede, sendikal yoğunluk ve toplu pazarlık kapsama oranları da yıllar itibariyle artış göstermektedir. Sendikal yoğunlukta gözlenen bu artışta hiç şüphesiz yenilenen hesaplama yöntemi, e-devlet üzerinden sendikaya üyelik ve alt işveren işçilerinin toplu pazarlık yapmasını kolaylaştıran düzenlemeler ile kamuda hizmet alımı yoluyla istihdam edilen ve 2018 yılında statüleri kamu işçisi olarak değiştirilen çalışanların sendikalaşmasının önemli bir etkisinin olduğu bilinmektedir (Çelik, 2019: 41; DİSK, 2019: 26). Ancak, Çelik (2018) sendikal yoğunluktaki bu artışın, sendikaların mücadeleleri sonucu sendikal gücün, etkinliğin ve kapasitenin artışından değil, daha çok siyaset kurumunun sendikalara sağladığ 1 bir takım kolaylık ve avantajlardan kaynaklanmadığını ileri sürmektedir.

Sendikal yoğunluktaki artışla birlikte, her iki tabloda da en dikkat çeken tuhaflık, toplu pazarlık kapsama oranlarının sendikal yoğunluktan daha düşük gerçekleşmesi (Çelik, 2019: 55; DİSK, 2019: 9) ve toplu pazarlık kapsama 
oranları ile sendikal yoğunluk arasındaki negatif farkın, her yıl artarak devam etmesidir. Oysa birçok gelişmiş ülkede toplu pazarlık kapsama oranlarının sendikal yoğunluktan çok daha yüksek olduğu yukarıda açıkça vurgulanmıştı. Türkiye'de toplu pazarlık kapsamı ile sendikal yoğunluk arasındaki bu ilişki, Türk endüstri ilişkiler sisteminin gelişmiş ülke endüstri ilişkileri sistemlerinden negatif ayrışmasına yol açmaktadır (Çelik, 2019: 55). Diğer taraftan, zaten çalışanların sendikaya üye olmalarındaki temel motivasyonun, sendikanın toplu pazarlık yoluyla ücret ve çalışma koşullarını koruyup geliştirmesi olmasına rağmen, bu oranlar Türkiye'de çalışanların bir kısmının, örgütlü oldukları halde, toplu pazarlık haklarını kullanırken, bir takım engellerle karşılaştıkları gerçeğini ortaya koymaktadır. Yorgun'a (2013) göre, toplu pazarlık kapsama oranının sendikal yoğunluktan daha düşük olmasının nedeni, "Türkiye'de yasa koyucunun toplu pazarlık hakkını sınırlandırmayı esas alması ve hakları ise, istisnai olarak vermeyi tercih etmesidir". Devrimci İşçi Sendikaları Konfederasyonu'nun (DİSK) (2019) yaptı̆̆ı, bir araştırmaya göre, sendikalı işçilerin bir kısmının toplu pazarlık kapsamı dışında kalmasının temel sebebi, anti-demokratik toplu pazarlık temsil yetkisi sistemidir. Ayrıca yetki alma sürecinin uzaması, yetki sürecinde sendika üyesi işçinin işten çıkarılması, toplu pazarlık sürecinin uzamasının yanı sıra, kamuya geçirilen işçilerin 2020'ye kadar toplu pazarlık hakkından mahrum bırakılması gibi nedenler de toplu pazarlık kapsama oranını düşürmektedir (DİSK, 2019: 28). $\mathrm{Bu}$ açıdan toplu pazarlık temsil yetkisinin ayrı bir başlıkta detaylı incelenmesi oldukça faydalı olacaktır.

\section{Toplu Pazarlık Temsil Yetkisi}

Sendikal örgütlenme özgürlüğü açısından "sendika çokluğu ilkesi" vazgeçilmez ilkelerden biri olmasına rağmen, bir toplu pazarlık biriminde (şirket ya da sektör) birden fazla sendikanın örgütlenmesi, toplu pazarlığın hangi sendika ile yapılacağı sorununu ortaya çıkarmaktadır. Örneğin, sendika çokluğu ilkesini benimseyen Japonya'da bir şirkette birden fazla işyeri sendikası bulunabilmekte ve ilkesel olarak, her bir sendika örgütlenme, toplu pazarlık ve toplu eylem yapma haklarına sahip olduğundan, böyle bir sendika çokluğu düzeni, Japonya' da tekdüze çalışma koşullarının oluşturulmasında bir takım karmaşıklıklara yol açabilmektedir (Yanagisawa, 2014: 2). Böyle bir durumla karşılaşmamak için, sendika çokluğu düzeninde "tek toplu pazarlık" ilkesi gereği, toplu pazarlık temsil yetkisini kullanmak üzere sendikalar 
içerisinden temsil gücü en yüksek olan sendikanın seçilmesi ve bu temsil gücünü belirlemeye yönelik bir takım ölçütlerin ya da kriterlerin bulunması gerekmektedir. Ancak ideal olarak, bu kriterlerin hem sendika özgürlüğünü kısıtlamaması, hem de sendikal gücün bölünmesine yol açmaması beklenir (Özveri, 2012: 112; Özveri, 2013: 63). Ulber’e (2011) göre, temsil yetkisi ölçütlerinin belirlemesinde bir taraftan sendikal çoğulculuk ve sendikalar arası rekabet ilkeleri korunurken, diğer taraftan toplu pazarlık biriminde temsil gücü en yüksek sendikaya bir takım ayrıcalıklar tanınarak, toplu pazarlık özerkliği ilkesine dikkat edilmesi gerekir (Engin, 2013: 158).

\section{Toplu Pazarlık Temsil Yetkisinin Karşılaştırmalı Analizi}

Sendika çokluğu ilkesini benimseyen gelişmiş ülkelerin, toplu pazarlık özerkliğini sağlamaya yönelik kendi iç dinamikleri içinde şekillenen, bir takım toplu pazarlık temsil yetkisi ölçüt ve kriterleri geliştirdikleri bilinmektedir. Bu kapsamda, yüksek toplu pazarlık kapsamına sahip model ülkeleri, temsil yetkisi kriterleri açısından, sendikal yoğunluğun yüksek olduğu ve düşük olduğu ülkeler olmak üzere iki kategoride inceleyebiliriz.

İlk olarak sendikal yoğunluğun görece yüksek olduğu ülkeler arasında, gent sistemine bağlı olarak \%50,3'lük sendikal yoğunluk ve \%96 ile neredeyse evrensel bir toplu pazarlık kapsama oranına sahip Belçika dikkat çekmektedir. Belçika'da sendika ve işveren örgütlerinin temsil yetkisi kriterleri, 1968 tarihli Toplu İş Kanunu'nda 2009'da yapılan değişiklikle yeniden düzenlenmiştir. Buna göre, bir sendika veya işveren örgütünün toplu pazarlıkta temsil yetkisine sahip olabilmesi için, en az 125.000 üyeye ulaşması, işçi veya işverenlerin sendika örgütü (ya da bir meslek örgütünün parçası) olmasının yanı sıra, özel ve kamu sektöründeki faaliyetlerin ve sektörlerin mutlak çoğunluğunu temsil etmesi gerekmektedir. Bir sendika bu kriterleri karşıladığında, toplu pazarlık yapma, ortak komitelerde temsil edilme ve Merkezi Ekonomik Konsey'de ve Ulusal Çalışma Konseyi'nde temsil yetkisi almaktadır (Van Oycke vd., 2019).

İkinci olarak, düşük bir sendikal yoğunluğa rağmen, nerdeyse evrensel bir toplu pazarlık kapsama oranı olan Fransa, en çok dikkat çeken ülkelerden biridir. Hemen belirtmek gerekir ki, Fransa'daki sendikal yoğunluk düşük olmasına karşın, işveren örgütlenme yoğunluğu görece yüksektir. Fransa'da 2008'de yapılan köklü değişiklikle, toplu pazarlık temsil yetkisi iki ayrı aşamadan oluşmaktadır. İlk aşamada, cumhuriyet değerlerine saygılı olmak, 
bağımsız olmak, finansal açıdan şeffaf olmak gibi (Engin, 2013: 156; Ulucan, 2013: 588) ön koşulları sağlayan sendikalar, ikinci aşamada bütün çalışanların katıldığı bir seçimde, işyeri düzeyinde oyların en az \%10’unu, sektörel düzeyde ise, \%8'ini toplaması durumunda, beş y1llık dönem için toplu pazarlık temsil yetkisi alabilmektedir (Colson vd., 2014: 6; Vincent, 2019: 226; Görmüş, 2018: 59-60).

İspanya \%13,6’lık sendikal yoğunluğa karşın, \%68'lik bir toplu pazarlık kapsama oranına sahip bir diğer ülkedir. İspanya'da sendikaların toplu pazarlık temsil yetkisini belirlemek için temel yasal kriter, işçi delegeleri ve işçi komitesi üyelerinin işyeri seçim sonuçlarına dayanmaktadır. Bu doğrultuda, çalışanların işyerindeki temsilcilerini belirlemeyi amaçlayan seçim süreci, aynı zamanda sendikal desteği ölçmek için de kullanılmaktadır. Böylece, temsil gücü en yüksek sendikalar, çok işverenli toplu pazarlık yapma, sosyal diyalog mekanizmalarına katılma ve işgücü çatışmalarının yargı dışı çözüm mekanizmalarında yer alma hakkına sahip olmaktadır (Molina, 2019).

\%34,4'lük bir sendikal yoğunluğa rağmen, toplu pazarlık kapsama oranı \%80'e ulaşan İtalya'da ise, Birleştirilmiş Temsil Kanunu, sendikaların temsil yetkisi statüsü kazanmak için seçimlerin nasıl yapılacağının şartlarını belirleyerek, temsil yetkisini seçimler yoluyla (en az \%5) tespit etmekte ve çatışma durumlarında yaptırımlar ve tahkim prosedürleri dahil, toplu pazarlık süreçlerinin sorumluluklarını ve TİS'lerin uygulanmasını tanımlamaktadır (Eurofound, 2015: 24). İtalya'da sendikal temsiliyeti ele alan bu Kanun temelinde, toplu pazarlık temsil yetkisi en son, 14 Ocak 2014 tarihinde işçi ve işveren üst örgütleri arasında imzalanan sektörler arası bir anlaşma ile belirlenmiştir. $\mathrm{Bu}$ anlaşmaya göre, sendikaların ulusal düzeye toplu pazarlık yapabilmeleri için, sendika üyelerinin ve aynı sendikaların 15 'ten fazla çalışanı olan işyerlerinde sendika delegelerinden oluşan işyeri temsil delegeleri seçimlerinde aldığı oyların ortalamasının \%5'lik bir temsil edilebilirlik eşiğine ulaşması gerekmektedir (Pedersini, 2019).

\%16,5'lik sendikal yoğunluk ve \%54'lük bir toplu pazarlık kapsama oranına sahip Almanya'da sendikaların temsil yetkisi, toplu pazarlık kapasitesi olarak ifade edilmekte ve sendikaların toplu pazarlık kapasitesi Federal İş Mahkemesi kararları ile belirlenmektedir. Buna göre, bir sendikanın toplu pazarlık kapasitesine sahip olabilmesi için, işveren ve üçüncü kişilere karşı bağımsız olması, sendika içi demokrasiye sahip olması ve işvereni toplu pazarlık 
masasına oturtacak ve TİS kazanımlarını uygulatacak sosyal gücünün olması gerekmektedir (Kraemer, 2018: 5; Görmüş, 2018: 41). Son olarak, 2015’te Toplu Pazarlığın Tekliği Kanunu ile bir şirkette aynı işçi grubunu kapsayan sendikaların toplu pazarlık aşamasında işbirliğine gitmeyerek, aynı işverenle farklı TİS'ler imzalamaları halinde, sadece toplu pazarlık birimindeki en fazla üyeye sahip olan sendikanın imzaladığı TİS'in uygulanacağı kuralı getirilmiştir (Kraemer, 2018: 5).

Ülkelerin endüstri ilişkileri sistemleri kendi tarihi, sosyal, ekonomik, siyasi ve kültürel yapısına bağlı olarak geliştiği için, endüstri ilişkileri sisteminin kurumsal özelliklerinden biri olan temsil yetkisi kriterlerinin, her bir ülkeye has özellikler taşıdığı görülmektedir. Bu anlamda incelenen ülkelerin temsil yetkisi kriterlerinin büyük ölçüde ülkelerin kendi iç dinamiklerinden gelen belirli bir sayıda üyeye sahip olma, yasal düzenleme, sosyal taraflar arası anlaşma, seçimde belirli bir oy eşiğine ulaşma ve yargı kararları ile şekillendiği görülmektedir.

\section{Türkiye'de Toplu Pazarlık Temsil Yetkisi}

Türkiye'de sendikal örgütlenme özgürlügü̈, demokratikleşme hareketi çerçevesinde, ilk kez 1947'de 5018 sayılı Sendikalar Kanunu ile tanınmasına rağmen, bu kanunda sendikalara grev hakkını içermeyen sadece genel sözleşmeler (umumi mukavele) yapma yetkisi verilmiştir. Ancak, 1961 Anayasası'nın kabulünden sonra, çalışanların sendikal örgütlenme ile birlikte toplu pazarlık ve grev hakkı, anayasal bir hakka dönüşmüş ve 1982 Anayasası'nda, sınırlandırılmış da olsa, aynı haklar korunmuştur. Her iki anayasa döneminde de sendikal hakların nasıl kullanılacağının yasama yoluyla detaylı bir şekilde düzenlenmesi, Türk endüstri ilişkilerinin çerçevesinin sendika ve işveren üst örgütleri arasında yapılan anlaşmalar ya da zaman içerisinde gelişen geleneklerden ziyade, yasalarla çizilmesine yol açmıştır.

Türkiye'de sendikal yoğunluk istatistikleri, işgücü içerisindeki sendikalı işçi sayısını göstermesinin yanı sıra, 1963’ten günümüze ortaya çıkan Türk endüstri ilişkileri yapısında, ücret sendikacılı̆̆ından öteye gidemeyen sendikalar için en görünür ekonomik faaliyet alanı olan (Özveri, 2012: 45) toplu pazarlıkta temsil yetkisi açısından da en temel kriter olmuştur. Örneğin 1963 'te çıkarılan 275 sayılı Toplu İş Sözleşmesi, Grev ve Lokavt Kanunu'na (TISGLK) göre, toplu pazarlık yapma yetkisi, işkolu düzeyinde federasyon 
veya işkolunda örgütlü sendikalara, işyeri ya da işyerleri düzeyinde ise, yerel sendikalara tanınmış ve temsil yetkisi tespitinde de, "iş kolunda çalışan işçilerin çoğunluğu" esası kabul edilmiştir. Ancak kanunla her ne kadar işyeri, işyerleri ve işkolu düzeyinde toplu pazarlıklar öngörülmüş ise de, bu dönemde işkolu toplu pazarlığından ziyade, işyerleri düzeyinde grup toplu pazarlığı ön plana çıkmıştır (Mahiroğulları, 2020: 199-200).

1963-1980 döneminde toplu pazarlık yetkisi için sendika üyeliğinde yapılan sahtecilikler ve çift üyelik uygulaması gibi usulsüzlükler ve sendikal rekabetin yarattığı olumsuzluklar (Özveri, 2013: 223) neticesinde, 1983’te çıkarılan 2821 sayılı Sendikalar Kanunu (SK) ve 2822 sayılı TİSGLK, toplu pazarlık temsil yetkisini kolaylaştırıp basitleştireceği ve önceki dönemde yaşanan sorunları gidereceği iddiasıyla kabul edilmiştir (Özveri, 2012: 112). $\mathrm{Bu}$ çerçevede, 2822 sayılı TISSGK'da federasyon, işyeri ve meslek esaslı sendikal örgütlenmeler yasaklanarak, işkolu düzeyinde toplu pazarlıklar kaldırılmış ve güçlü sendikacılık anlayışı çerçevesinde, işyeri/işyerleri ve işletme düzeyinde toplu pazarlık yapma yetkisi, sadece ülke genelinde faaliyet gösteren işkolu sendikalarına tanınmıştır (Özveri, 2013: 211). Ayrıca, 1983 sonrası dönemde güçlü sendikacılık adına, toplu pazarlık temsil yetkisinde ilk defa ikili baraj sistemine geçilerek, sendikaların toplu pazarlık temsil yetkisi için işkolunda \%10 ve işyeri/işyerleri ve işletmede ise, çalışanların yarıdan bir fazlasını (\%50+1 işçi) üye kaydetmesi kuralı getirilmiştir. Ancak 1983 sonrası dönemde yetkili sendikayı belirlemek için uygulamaya konulan bu ikili baraj sistemi, toplu pazarlık sürecinin işleyişini iyice zorlaştırmış ve darbe koşullarının bir ürünü olduğu, uygulamada ortaya çıkan sorunlar ve ILO'nun 98 sayılı Sözleşmesi'ne aykırılıkların olduğu yönünde eleştirilere maruz kalmıştır (Kutal, 2014: 21; Özveri, 2012: 112-113).

2822 sayılı TİSGLK ile hem her yıl ocak ve temmuz aylarında işkolu barajına esas istatistiklerin yayımlanması, hem de işyeri/işyerleri ve işletmedeki salt çoğunluk tespiti görevi bugünkü adıyla AÇSHB'ye verilmiştir. Fakat zaman içerisindeki uygulamalar ve resmi gazetede açıklanan işkolu istatistikleri ile fiilen gerçekleşenler arasında oluşan farklar nedeniyle, Bakanlık verilerinin güvenirliği şüpheli hale gelmiştir (Mahiroğulları, 2001: 127). Çelik ve Lordoğlu'na (2006) göre, sendikal yoğunluk istatistiklerinin toplu pazarlık temsil yetkisi üzerindeki belirleyici rolünün yanı sıra, siyasal ve sosyal kaygılar ile birlikte sendikalar arası rekabet, resmi işkolu istatistiklerini 
siyasal ve sosyal tarafların müdahalesine açık hale getirmiş ve güvenirliğini zedelemiştir.

Nihayet 30 yıllık uygulamanın ardından, 2821 sayılı SK ve 2822 sayılı TİSGLK'nın yerine, sendikacılığı teşvik etmek ve güçlendirmenin yanı sıra, ILO'nun eleştirileri ve temsil yetkisi başta olmak üzere birçok sorunlara çözüm bulmak gerekçeleriyle (Dereli, 2013: 42; Kutal, 2014: 15; Engin, 2013: 144), 2012 yılında 6356 sayılı STİSK kabul edilmiştir. 6356 sayılı Kanun'da toplu pazarlık yetkisi için ikili baraj sistemi korunarak, uzun tartışmalar ve Anayasa Mahkemesi'nin iptal kararının ardından, işkolu barajı \%1'e çekilmiş ve işyerinde çalışanların $\% 50+1$ 'inin, işletmede ise, $\% 40$ ' 1 nın temsil yetkisi talebinde bulunan sendikanın üyesi olması zorunluluğu getirilmiştir. Toplu pazarlık birimi işletmede birden fazla sendikanın \%40 çoğunluğu geçmesi halinde ise, temsil yetkisinin en çok üyesi bulunan sendikaya verilmesi esası getirilerek, tek toplu pazarlık ilkesi korunmuştur (Sur, 2013: 341). Kutal'a (2014) göre, toplu pazarlık temsil yetkisinde işkolu barajının \%1'e indirilerek ikili baraj sistemine devam edilmesi, Türkiye'yi ILO'nun eleştirilerinden kurtaramayacaktır. Nitekim ILO Uzmanlar Komitesi'nin 2019 yılı Raporu'nda, Türkiye'de toplu pazarlık temsil yetkisi için uygulanan \%1'lik işkolu barajının, sosyal taraflara danışılarak toplu pazarlık mekanizmasının kapsamını olumsuz etkilediği sonucuna varılması halinde, kaldırılması için gerekli tedbirlerin alınması talep edilmiştir. Ayrıca Komite aynı raporda, hiçbir sendikanın işyerinde $\% 50+1$, işletmede ise, $\% 40$ üye yoğunluğuna ulaşamaması halinde, toplu pazarlık birimde örgütlü tüm sendikalara, birlikte veya ayrı ayrı, en azından kendi üyeleri adına toplu pazarlık yapma hakkı tanıyan bir düzenlemenin, sosyal taraflara da danışılarak, yapılmasını talep etmiştir (ILO, 2019: 169-170).

Tablo 3

Türkiye'de Yıllara göre İskolu Barajını (\%1) Geçen Sendika Sayıları

\begin{tabular}{lcccccccc}
\hline & $\mathbf{2 0 1 3}$ & $\mathbf{2 0 1 4}$ & $\mathbf{2 0 1 5}$ & $\mathbf{2 0 1 6}$ & $\mathbf{2 0 1 7}$ & $\mathbf{2 0 1 8}$ & $\mathbf{2 0 1 9}$ & $\mathbf{2 0 2 0}$ \\
\hline $\begin{array}{l}\text { İskolu barajını geçen sendika } \\
\text { sayısı }\end{array}$ & 42 & 47 & 48 & 55 & 55 & 55 & 55 & 56 \\
$\begin{array}{l}\text { İşkolu barajının altında kalan } \\
\text { sendika sayısı }\end{array}$ & 48 & 68 & 99 & 111 & 106 & 109 & 117 & 129 \\
$\begin{array}{l}\text { Toplam sendika sayısı } \\
\begin{array}{l}\text { İskolu barajını geçen } \\
\text { sendikaların oranı }\end{array}\end{array}$ & 90 & 115 & 147 & 166 & 161 & 164 & 172 & 185 \\
\hline
\end{tabular}

Kaynak: AÇSHB, Sendikal İstatistikler, Ocak 2013-Ocak 2020. 
2013 yılından itibaren, Türkiye' de gerek sendika sayısı, gerekse sendikalı işçi sayısı önemli ölçüde artmıştır. 2013-2020 yılları arasında sendikalı işçi sayısı 900 binden fazla artarken, sendika sayısı da 90'dan, 185'e çıkmıştır. Ancak Kutal (2014), yeni dönemde işkolları sayısının 28'den 20'ye düşülmesiyle bazı işkollarındaki işçi sayısındaki artışa bağlı olarak, toplu pazarlık temsil yetkisine sahip olabilecek sendika sayısının azalabileceğini öne sürmüştür. Bu açıdan Tablo 3'e bakıldığında, işkolu barajını geçen sendika sayısı, sistemin uygulanmaya başladığı 2013 yılında 42'den 2020 yılında 56'ya çıkmasına rağmen, aynı dönemde işkolu barajının altında kalan sendikaların sayısı da 48'den 129'a yükselmiştir. İşkolu barajını geçen sendikaların oranı ise, sadece 8 yıl içerisinde, yeni açılan sendikaların etkisiyle 2013'te \%46,7'den 2020'de \%30,3'e kadar gerilemiştir. Ayrıca, işkolu barajını geçtiği halde, işyeri ve işletme barajlarına takılan sendikalar da düşünüldügünde, toplu pazarlık yetkisi alabilen sendikaların oranı çok daha aşağılara inmekte ve hatta yeni kurulan sendikaların toplu pazarlık yetkisi alabilmeleri çok daha zorlaşmaktadır. Bu tablo, Kutal'ın iddiasının ne kadar haklı olduğunu ortaya koymakta ve sendikal yoğunluğun bu denli düşük olduğu bir ortamda, \%1'lik bir işkolu barajının bile, toplu pazarlık hakkını ne derecede kısıtladığını açıkça göstermektedir (Engin 2013: 147). Ayrıca DİSK' in (2019) yayınladığ1 bir raporda da bu duruma dikkat çekilerek, \%1'lik yeni işkolu barajının, yeni kurulan sendikaların toplu pazarlık yapmasını olanaksız hale getirdiği ve temel olarak örgütlenmelerini engellediği yönünde eleştirilmektedir.

6356 sayılı Kanun döneminde, AÇSHB'nin her y1l ocak ve temmuz ayında sendikal işkolu istatistiklerini yayımlamanın yanı sıra, toplu pazarlık birimindeki yetkili sendikayı tespit etme görevleri devam etmekle birlikte, işkolu istatistiklerinin tespitinde Bakanlık artık kendisine bilindirilen üyelik ve üyelikten çekilme bildirimleri ile SGK'ya yapılan işçi bildirimlerini esas almaktadır. Yeni dönemde, önceki dönemde olduğu gibi, Bakanlığın yetki tespitindeki merkezi konumu korunarak, sendika üyeliğinde noter zorunluluğu kaldırılmış ve sendikaya üyeliğinin e-devlet üzerinden yapılmasına geçilerek, sendikaya üyelik kolaylaştırılmıştır. Bütün bu düzenlemelerle, önceki dönemde çok sık yaşanan sahte üyelik, çalışan sayısının fazla gösterilmesi gibi sahteciliklerin önüne geçilmesi (Özveri, 2012: 117) ve gerçek sendikal yoğunluğun yansıtılması (Çelik, 2019: 40) hedeflenmiştir. Bu düzenlemeyi eleştiren Engin'e (2013) göre, 2822 sayılı TISGLK döneminde, uygulanan \%10 işkolu barajı, Bakanlığın şişirilmiş istatistikleri sayesinde dikkate 
alınmıyor ve böylece sendikaların toplu pazarlık yapması önünde önemli bir engel oluşturmuyordu. Ancak yeni dönemde işkolu istatistiklerinin tespitinde SGK işçi bildirimlerinin esas alınması ile Bakanlık işkolu barajı üzerindeki takdir imkanını kaybetmiş ve 6356 sayılı Kanun ile getirilen toplu pazarlık temsil yetkisi ile 2822 sayılı Kanun'dan daha geriye gidilmiştir. Dolayısıyla \%1'lik işkolu barajı toplu pazarlık hakkı açısından daha büyük bir engel oluşturmaya başlamıştır (Engin, 2013: 151). Bütün bu eleştiriler, 6356 sayılı Kanun döneminde de toplu pazarlık hakkını sınırlandıran yasal ve kurumsal engellerin sürdüğünü göstermektedir (Çelik, 2019: 40).

\section{Toplu Pazarlık Düzeyi ve Koordinasyon Derecesinin Karşılaştırmalı Analizi}

Toplu pazarlığın düzeyi, toplu pazarlığın etki alanını da belirlediği için çalışanlar ve işverenler açısından son derece önemlidir. Toplu pazarlığın düzeyi her ülkenin sosyo-ekonomik yapısı, endüstri ilişkileri gelenekleri, şirket özellikleri ve işverenlerin örgütlenme yoğunluğu, sendikaların eğilimleri ve hükümetlerin izledikleri sosyal politikalar vb. birçok faktöre bağlı olarak değişmektedir (Görmüş, 2012: 34). Kural olarak, her ülkenin iş hukuku ile belirlenen belirli sınırlar dahilinde, toplu pazarlık tarafları müzakereler için uygun düzeyi veya belirli düzeylerin karışımını seçmekte serbesttir. Bu açıdan, bir ülke içerisinde toplu pazarlıklar üç temel düzeyde yürütülebilmektedir. En üst seviyede yürütülen ulusal düzeyde pazarlıklar, sendika ve işveren tepe örgütleri ile devlet kurumları arasında iki veya üç taraflı müzakere ya da danışma yapıları biçiminde yürütülmektedir. Bu tür müzakere ya da danışma yapıları genellikle makro-ekonomik hedefleri de göz önünde bulundurarak, istihdam koşullarıyla ilgili daha düşük düzeyli toplu pazarlıklar için bir zemin oluşturmayı amaçlamaktadır. Örneğin Belçika, Finlandiya, Hollanda ve Norveç'te ulusal çapta toplu pazarlık biçimleri görülmektedir. Bir sektördeki istihdam koşullarının standartlaştırılmasını amaçlayan sektörel pazarlık ise, kapsanan sektörel faaliyetler açısından, geniş veya dar olarak tanımlanabilmekte ve bölgesel alt birimlere göre bölünebilmekte veya ulusal düzeyde yürütülebilmektedir (Traxler, 1994: 170). Sektör düzeyinde yapılan toplu pazarlıklar, taraf işverenler arasında ortak çalışma koşulları oluşturmakta ve aynı zamanda çok işverenli toplu pazarlık olarak da nitelendirilmektedir (Oesingmann, 2016: 59). Sektörel toplu pazarlıklar İskandinav ülkelerinin yanı sıra, Avusturya, Almanya, Hollanda ve İsviçre’ye özgü bir özelliktir. 
Üçüncü ve en alt seviyede toplu pazarlıklar, şirket ve/veya işyeri düzeyinde de yürütülebilmektedir. Şirket ve/veya işyeri düzeyinde toplu pazarlıklar Kanada, ABD, Birleşik Krallık ve Japonya'da baskın toplu pazarlık türü iken, farklı düzeylerdeki toplu pazarlıkların iççice geçtiği bazı Avrupa ülkelerinde, tamamlayıcı bir toplu pazarlık türü olarak görülmektedir (Traxler, 1994: 171).

1980'lerin sonlarından bu yana, birçok OECD ülkesinde adem-i merkezi, yani şirket veya işyeri düzeyindeki toplu pazarlığı destekleyen birçok reform yapılmıştır. Bu adem-i merkezileşme genellikle ya şirket düzeyindeki toplu pazarlıların doğrudan ulusal veya sektörel düzeydeki toplu pazarlıların yerini alması (kontrolsüz adem-i merkezileşme) ya da daha üst düzeyde müzakere edilen genel bir çerçevede, ücret ve çalışma koşullarını müzakere etmek için şirket düzeyinde toplu pazarlıklara izin veren ulusal/sektörel toplu pazarlıklar dahilinde bir eklemleme/yetki devri süreci (kontrollü adem-i merkezileşme) yoluyla iki şekilde gerçekleşmektedir. Toplu pazarlılardaki kontrollü adem-i merkeziyetçilik, Avrupa ülkelerinde iki şekilde uygulanmaktadır. İlkinde, ulusal veya sektörel düzeyde bağıtlanan TíS 'ler, geniş çerçeveyi tanımlamakta, ancak özellikle İskandinav ülkelerinde veya Hollanda'da olduğu gibi, şirket düzeyindeki toplu pazarlık için geniş bir alan bırakılmaktadır. Bu anlamda sektörel toplu pazarlıklar, işverenlerin şirket düzeyinde tamamlayabileceği veya sapabileceği minimum veya standart istihdam koşullarını belirleyebilir; ya da işçilerin ve işverenlerin, istedikleri çalışma koşullarına uygun ücretleri (alakart ve denkleştirme) seçmelerine izin vermektedir. İkinci kontrollü adem-i merkeziyetçilik biçimi ise, Almanya'da olduğu gibi, ulusal veya sektörel TİS’lerde, genel açı hükümler (general opening clauses) ${ }^{2}$ ve geçici sapma hükümleri (temporary oup-out clauses) ${ }^{3}$ yoluyla, daha düşük düzeylerdeki TİS'lere sapma izni verilmekte ve sapma istisnaları için gerekli koşullar tanımlanmaktadır (OECD, 2017: 147). Almanya'da istihdamın sürdürülebilirliği veya yeni istihdam alanlarının yaratılması veya bir şirketin rekabet edebilirliğinin arttırılması için istisnaların mümkün olduğu genel açık hükümler ve geçici sapma hükümleri yoluyla belli konuların düzenlenmesi şirket düzeyine devredilmektedir. Bunun mümkün olduğu koşulları tanımlayan genel açık hükümler ve geçici sapma hükümleri Almanya'da ilk önce çalışma süresi ile sınırlı olmak üzere geçici bir çözüm olarak başlatılmış ve 1995 'ten

2 İşyeri ya da şirket düzeyindeki TİS'lere daha üst düzey TİS'lerde (sektör vb.) belirlenen minimum seviyelerden veya standartlardan sapmasına imkan veren sözleşme hükümleridir (Keune, 2010: 1).

3 Ekonomik sıkıntı dönemlerinde Tís koşullarııın (işyeri düzeyindeki Tís'ler de dahil) askıya alınmasına (veya yeniden müzakere edilmesine) imkan tanıyan sözleşme hükümleridir (Keune, 2010: 1). 
sonra ücretlere kadar genişletilmiş, son olarak 2000'lerden sonra yaygın hale gelmiştir (Müller ve Schulten, 2019: 248; OECD, 2017: 150).

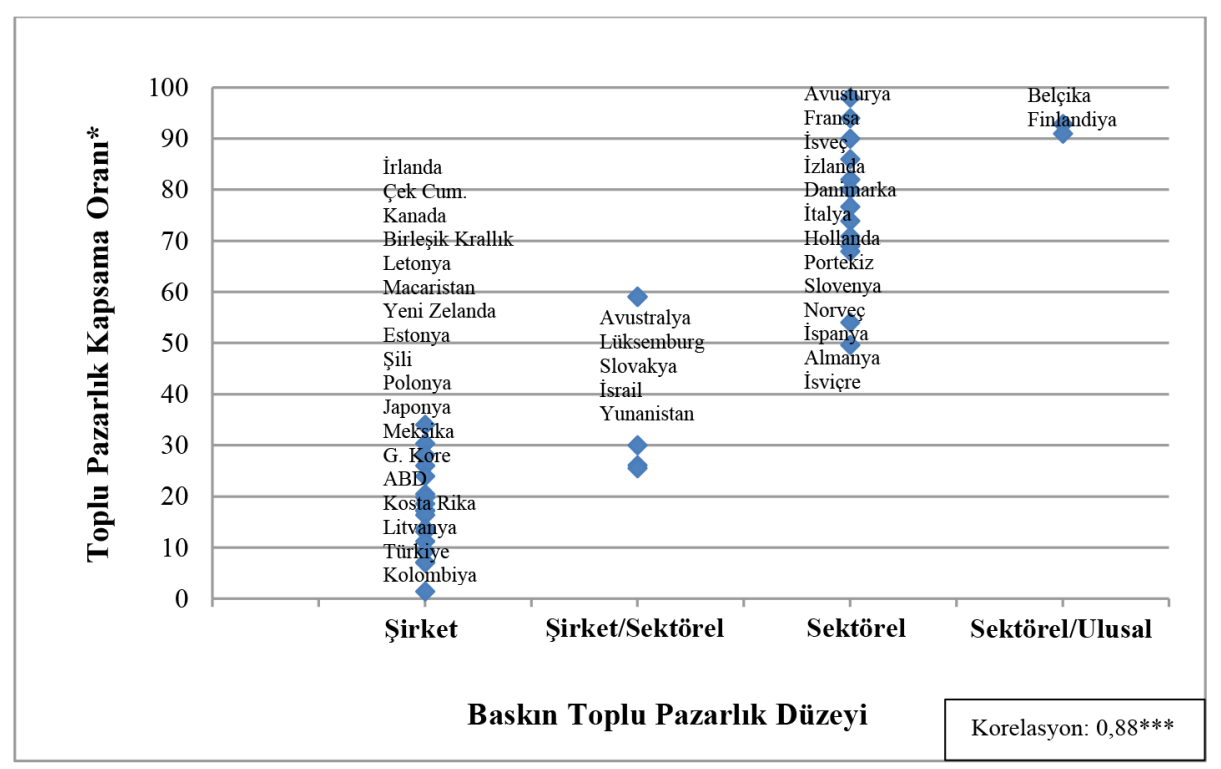

Grawfik 4. Toplu pazarlık kapsama oranı ile baskın toplu pazarlık düzeyi arasındaki ilişki *** 0,001 düzeyinde istatistiksel olarak anlaml

Kaynak: OECD, 2017: 164; * Visser, (2019), ICTWSS Database Version 6.1

Not: Ülkeler toplu pazarlık kapsama oranı açısından yukarıdan aşağı sıralanmıştır.

Grafik 4'te gösterilen toplu pazarlıkta aynı baskınlık düzeyine sahip ülkeler arasında toplu pazarlık yapıları açısından önemli ölçüde farklılıklar bulunmaktadır. Örneğin sektörel toplu pazarlı̆̆ın baskın düzey olduğu ülkelerde bile, şirket düzeyinde toplu pazarlıklar çok önemli bir role sahip olabilir veya tersi de geçerlidir. Grafik 4'te gösterildiği gibi, sektör düzeyindeki toplu pazarlıklar çoğu Batı Avrupa ülkesinde baskın olmaya devam ederken, Kanada, Şili, İrlanda, Japonya, Kore, Meksika, Türkiye, Yeni Zelanda, Birleşik Krallık, ABD, çoğu Orta ve Doğu Avrupa ülkesinde, baskın toplu pazarlık türü şirket düzeyidir. Son olarak, Avustralya, İsrail, Lüksemburg, Slovakya ve Yunanistan'da sektör ve şirket düzeyinde toplu pazarlıklar neredeyse eşit bir kombinasyona sahiptir (OECD, 2017: 147). Grafik 4'te toplu pazarlık kapsama oranları ve baskın toplu pazarlık düzeyleri arasında doğrusal yönde yüksek düzeyli anlamlı $(\mathrm{r}=0,88 ; \mathrm{p}<0,001)$ bir korelasyon görülmektedir. $\mathrm{Bu}$ sonuç, merkezi düzeydeki toplu pazarlıkların baskınlığı arttıkça, toplu pazarlık kapsama oranlarının da anlamlı bir şekilde arttığı anlamına gelmektedir. 
Toplu pazarlıklar ayrıca, toplu pazarlık yapılarının bir diğer temel direği olan, pazarlık düzeyleri arasındaki koordinasyon derecesi ile de karakterize edilmektedir(Traxler, 1994: 171). Koordinasyon, "endüstri ilişkilerinde küçük aktörlerin bilinçli bir şekilde büyük aktörlerin toplu pazarlıkla belirlenen ücret ve çalışma koşullarını takip etme derecesi" anlamına gelmektedir (OECD, 2017: 152). Traxler’e (1994) göre, toplu pazarlığın koordinasyonu, farklı düzeylerdeki toplu pazarlıkların kendi amaçlarını karşılıklı olarak engellemesini önlemek için farklı düzeylerin ne ölçüde birbirine entegre edildiğini ifade etmektedir. Örneğin, makroekonomik hedefler üzerinde yürütülen ulusal çaptaki toplu pazarlığın başarılı olabilmesi, sektörel düzeydeki toplu pazarlıkların ulusal çaptaki toplu pazarlığa saygı duymasını sağlama yeteneğine bağlıdır (Traxler, 1994: 171).

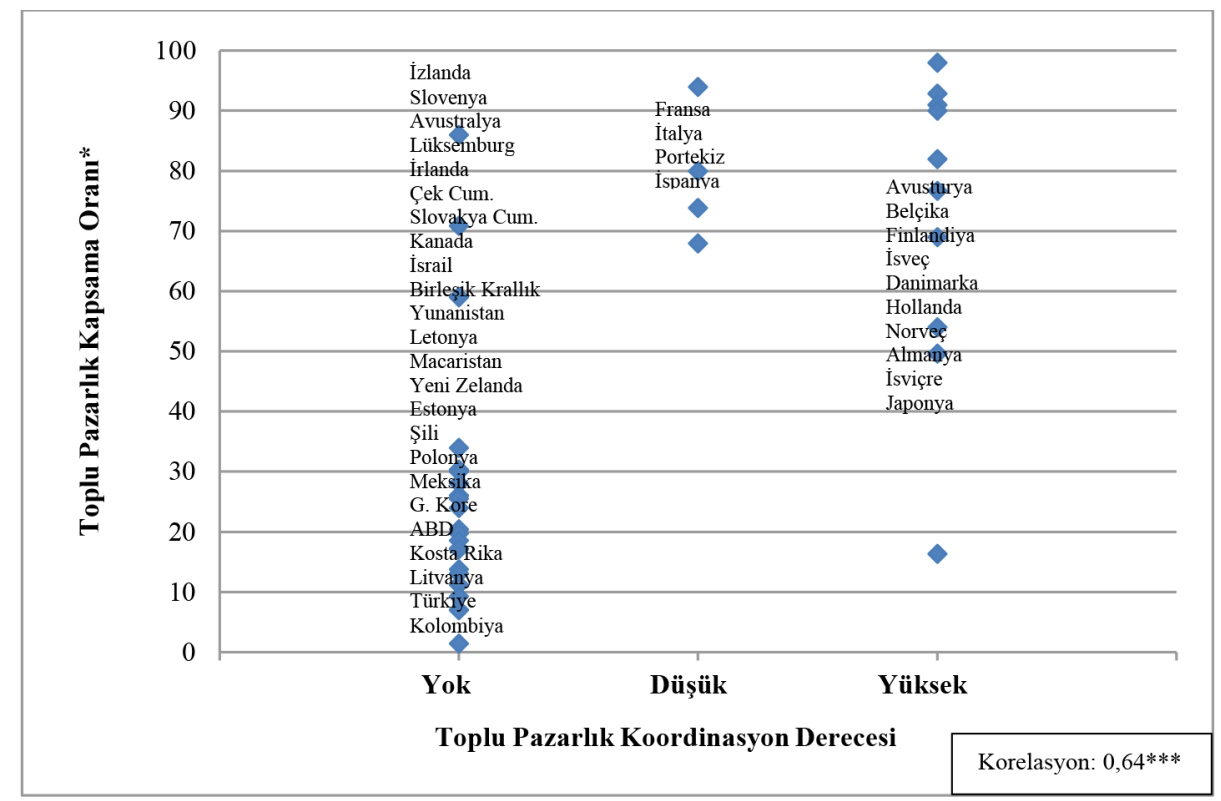

Grafik 5. Toplu pazarlık kapsama oranı ile toplu pazarlık koordinasyonu arasındaki ilişki *** 0,001 düzeyinde istatistiksel olarak anlamlı

Kaynak: OECD, 2017: 164; * Visser, (2019), ICTWSS Database Version 6.1

Not: Ülkeler toplu pazarlık kapsama oranı açısından yukarıdan aşağı sıralanmıştır.

Grafik 5'te gösterildiği gibi, toplu pazarlık kapsama oranları ile toplu pazarlık düzeylerinin koordinasyon derecesi arasında doğrusal yönde orta düzeyli anlamlı $(\mathrm{r}=0,64 ; \mathrm{p}<0,001)$ bir korelasyon görülmektedir. $\mathrm{Bu}$ sonuca göre, İzlanda, Slovenya ve Avusturalya'da toplu pazarlıklar arası koordinasyon olmamasına rağmen, toplu pazarlık kapsama oranının yüksek 
olmas1; Japonya'da koordinasyonun yüksek olasına rağmen, toplu pazarlık kapsama oranının düşük olması, bu iki değişken arasındaki korelasyonu düşüren bir etki oluşturmaktadır.

Toplu pazarlık koordinasyonu, farklı düzeylerdeki pazarlık birimleri arasında örneğin, sektör veya şirket/işyeri düzeyindeki pazarlıkların, tepe örgütler veya bir sosyal pakt ile belirlenen ilke ve çerçeveleri takip ettiğinde (dikey koordinasyon) olabileceği gibi, aynı düzeydeki pazarlık birimleri arasında da örneğin, bazı sektörel veya şirket/işyeri düzeyindeki toplu pazarlıklar başka bir sektörde/şirkette belirlenen standartları takip ettiğinde (yatay koordinasyon) de olabilmektedir (OECD, 2017: 152). Genel olarak sektörel toplu pazarlıklar, çalışma koşullarıyla ilgili şirket düzeyindeki toplu pazarlığın seyrini iyileştirilebilecek bir zemin oluşturmaktadır. Diğer taraftan, sektör içindeki toplu pazarlığın koordinasyonu, öncü toplu pazarlığı takip eden model toplu pazarlıklar yoluyla gerçekleşmektedir (Traxler, 1994: 171).

\section{Genişletme Mekanizması (Teşmil)}

Endüstri ilişkileri sistemlerinde, model bir ülkede toplu pazarlık kapsamındaki çalışan oranının, sendikal yoğunluktan daha yüksek olması gözlenen bir durumdur. Bu durum, çoğu kez bir TİS'in sadece toplu pazarlık tarafları ve onların üyeleri için değil, bir genişletme kararı ya da hükmü yoluyla, yasal şartlara bağlı olarak, bir sektördeki ve/veya coğrafi alandaki tüm işletme ve işçilere de otomatik olarak uygulanması ile açıklanabilir. Prensip olarak, "ikili bağlılık kuralı" (double affiliation principle) gereği, TIS'ler sadece imzacı pazarlık tarafları ve onların temsil ettiği üyeleri için geçerlidir. Ancak genişletme mekanizması yoluyla, toplu pazarlık yoluyla oluşturulan ücret ve çalışma koşulları, sadece toplu pazarlık tarafı sendika üyelerini değil, aynı zamanda ilgili işyerleri, ekonomik sektör veya coğrafi bölgedeki tüm çalışanlar için geçerli hale gelmektedir (ILO, 2018: 18; OECD, 2017: 140; Oesingmann, 2016: 59-61; Villanueva, 2015: 2). Bu nedenle, bir endüstri ilişkileri sisteminde genişletme mekanizmasının mevcut olup olmadığı ve kullanılıp kullanılamayacağı, eğer varsa hangi koşullar altında kime uygulanacağ 1 ve temsil kriterleri vb. konularda bilgi sahibi olmak son derece önemlidir (ILO, 2018: 18). 
Genişletme mekanizmaları genellikle hükümet, bir kamu kurumu veya bazı durumlarda bir mahkeme kararı ile bir TİS'in, imzacı tarafların ötesinde uygulanmasını zorunlu kılan ve açık bir yasal düzenlemeye dayanan bir "kamu politikası eylemidir" (OECD, 2017: 141). Bu açıdan, bazı ülkelerde bu kamu politikasının bazı kriterleri varken, bazı ülkelerde genişletme mekanizması otomatik olarak işletilmektedir. Örneğin Almanya'da, herhangi bir genişletme kararının Çalışma Bakanlığı'ndaki üçlü komite tarafından tavsiye edilmesi gerekmekte ve ayrıca işverenler de bu kararı fiilen veto edebilmektedir (OECD, 2017: 141).

TİS’lerin sık sık genişletilmesi, devletin işverenler ve çalışanlar arasındaki özerk toplu pazarlık sürecine müdahale ettiği yönünde eleştirilmektedir. Ayrıca TİS'lerin devlettarafından sıklıkla genişletilmesi, Fransa' daki gibi, işverenlerin toplu pazarlık sürecine katılabilmek için gönüllü olarak işveren örgütlerine üye olma eğilimini artırıyorken (Oesingmann, 2016: 63), çalışanların, herhangi sendika üyeliği olmaksızın, TİS olanaklarından "bedavadan yararlanması" (free ride) (Mouret, 2007: 34-35), işçilerin sendikaya üye olma eğilimleri azaltan bir etki oluşturabilmektedir (OECD, 2017: 141). Ancak Finlandiya örneği, genel bağlayıcı TİS sisteminin uygulanmasından kısa bir süre sonra, mekanizmanın hem işveren, hem de çalışan tarafında örgütlenme yoğunluğunu birlikte artabileceğini göstermiştir. Finlandiya'da çalışanların, genel bağlayıcı TíS ile belirtilen haklarını uygulatmak için sendikalara olan ihtiyacı artarken, işverenler de, genel bağlayıcı TİS'leri yorumlamak ve yönetmek için işveren örgütlerinin yardımına ihtiyaç duymuşlardır (Malmberg, 2002: 207).

Genişletme mekanizmasının fayda ve maliyetlerini araştıran Villanueva’ya (2015) göre, toplu pazarlık kapsamının yükseltilmesinin işçi ve işverenler üzerinde bir takım olumlu ve olumsuz etkileri bulunmaktadır. Olumlu tarafta, genişletilme mekanizmalarının kullanımı, bir sektörde mesleğe özgü ücretlerin alt limitini belirleyerek, ücret eşitsizliğini azaltırken, ücret dağılımının alt kısmında, cinsiyetler arasındaki ücret farklarını düşürmektedir. Ayrıca, aynı işte uzun süreli çalışanlara, geçici verimlilik dalgalanmalarına veya iş döngüsüyle ilişkili ekonomi genelindeki dalgalanmalara karşı güvence sağlarken, işler arasında tam mobilitenin olmadığ 1 durumlarda, iş kalitesinde ve ücretlerde firsatçı azalmaları önlemektedir. Olumsuz tarafta ise, genişletmeler yoluyla sektör genelinde ücretlerin eşitlenmesi, istihdam artışını engelleyerek, kapsam içindeki tüm işyerlerinin işgücü maliyetlerini artırmakta 
ve pazarlık sürecine katılmayan işverenlere ve çalışanlara toplu pazarlık yoluyla belirlenen çalışma koşullarını uygulama zorunluluğu getirmektedir. Ayrıca genişletmeler piyasaya giriş ve küçük işletme yatırımlarının cesaretini kırarak, rekabeti azaltmakta ve işyerlerinin ekonomik şoklara uyum sağlama kabiliyetini sınırlayan ücret katılıkları oluşturmaktadır (Villanueva, 2015: 1).

\section{Genişletme Mekanizmasının Karşılaştırmalı Analizi}

Genişleme mekanizmaları temel olarak, başlatma inisiyatifini kimin alacağı, genişletme için minimum gereklilikler olup olmadığı ve kullanım sıklıkları açısından, uygulandığı ülkeye göre değişkenlik göstermektedir (Eurofound, 2015: 27).

Genişletme prosedürü, Avusturya, Belçika, Finlandiya, Fransa, Yunanistan, Lüksemburg ve İspanya'da olduğu gibi, yetkili devlet kurumu tarafından otomatik veya yarı otomatik olarak başlatılabilmektedir (Eurofound, 2015: 27). Örneğin Fransa'da, genişletme prosedürü hem toplu pazarlık taraflarının talebiyle, hem de Çalışma Bakanlığı'nın inisiyatifi ile başlatabilmektedir. Fransa'da erga omnes ${ }^{4}$ kuralı kabul edildiğinden, TİS imzalayan işveren örgütü tarafından temsil edilen tüm işyerleri, TİS ile belirlenen koşullara tabidir (Villanueva, 2015: 2; Oesingmann, 2016: 60; Bayc1k, 2019: 22). Diğer taraftan, hem sosyal taraf temsilcilerinden oluşan komisyondan, hem de Ulusal Toplu Pazarlık Komisyonu'ndan olumlu görüş alınması koşuluyla, temsil kabiliyeti olan sendika (\%30) ve işveren örgütlerinin (\%50) talebi üzerine veya Çalışma Bakanlığı'nın inisiyatifi ile sektör düzeyindeki bir TİS'i, sektördeki tüm işçilere genişletmek de mümkündür (Villanueva, 2015: 2; Oesingmann, 2016: 60; Bayc1k, 2019: 23).

TİS'lerin neredeyse genel veya evrensel olarak bağlayıcı nitelikte olduğu Finlandiya'da ise, ilk kez 1970 yılında İş Sözleşmeleri Kanunu ile getirilen 2001 'de değiştirilen genişletme düzenlemesine göre, genişletme kararı üç taraflı özel bir kurul tarafindan verilmektedir (Baycık, 2019: 21). Kurul tarafindan, kendi sektöründe temsil kabiliyeti olduğu kabul edilen bir TİS, genel olarak bağlayıcı ilan edilirse, otomatik olarak, işverenler söz konusu TİS'de öngörülen istihdam koşullarını ülke çapında uygulamakla yükümlüdür (Malmberg, 2002: 207; Eurofound, 2011: 5).

4 Kanun yoluyla ya da standart bir uygulama (de fakto) olarak, TİS'lerin sadece imzacı sendika üyelerini değil, aynı zamanda pazarlık birimindeki tüm çalışanları kapsamasıdır (OECD, 2017: 141). 
İspanya'da ise, temsil edilebilirlik kavramı, hem sendikalar, hem de işveren örgütleri için erga omnes temsilini garanti etmektedir (Molina, 2019). $\mathrm{Bu}$ yüzden, toplu pazarlıkta temsil yetkisini alan sendikalar ve işverenler imzaladıkları TİS’i Çalışma Bakanlığı'na kayıt ettirdiklerinde genişletme otomatik olarak gerçekleşmektedir. $\mathrm{Bu}$ açıdan, İspanya'da genişletme mekanizması, işverenlerin ve çalışanların referandum oylamasına tabi değildir (Villanueva, 2015: 2). Ancak İtalya'da 2014'de çıkarılan Kolektif Temsil Kanunu'na göre, ulusal çaptaki TİS’ler belirli bir temsil eşiğine ulaşan sendikalar tarafindan imzalansa bile, referandum yoluyla işçiler tarafından onaylanması koşuluyla, otomatik olarak sektördeki tüm çalışanlar için bağlayıcı hale gelmektedir (Pedersini, 2019; Eurofound, 2015: 27).

Alternatif olarak, genişletme prosedürü, Almanya, Hollanda, Portekiz ve Litvanya'da olduğu gibi, toplu pazarlık taraflarından birinin veya her ikisinin talebi üzerine de başlatılabilmektedir (Eurofound, 2015: 27). Örneğin Almanya' da Toplu İş Sözleşmesi Kanunu'na göre, toplu pazarlık taraflarından birinin talebi üzerine, tarafları temsil eden 7 üyeden (1 kamu, 3 sendika ve 3 işveren) oluşan Toplu Pazarlık Komitesi'nin genişletmeyi oy çokluğu ile kabul etmesi halinde, eyalet ya da Federal Çalışma Bakanlık'larının "genişletme emriyle" TİS'ler genişletilebilmektedir (Müller ve Schulten, 2019: 246). Hollanda'da ise, 1937'da çıkarılan Toplu İş Sözleşmelerinin İdari Genişletilmesi Hakkında Kanun'a göre, sektörel düzeydeki TİS'leri genişletme prosedürü, bir veya her iki pazarlık tarafının talebi üzerine başlatılmakta ve Sosyal İşler ve İstihdam Bakanlığı'nın onayı ile genişletme belirli bir sektördeki tüm çalışanlar ve işverenler için geçerli hale gelmektedir (Eurofound, 2011: 8). Diğer taraftan çoğu ülke için nihai karar, ilgili Bakanlıklar tarafindan verilirken, Finlandiya'da, genişletmeyi iş mahkemesinde temyize götürmek mümkündür (Eurofound, 2015: 27).

Minimum gerekliliklerin sağlanması koşulu olan mekanizmalar için, bu koşul genellikle toplu pazarlık taraflarının veya TİS'in temsil etme eşiğidir ve bu eşik ülkelere göre değişkenlik göstermektedir (Eurofound, 2015: 27). Örneğin Finlandiya'da, belirli bir sektördeki çalışanların yarısı veya daha fazlası TİS kapsamındaysa, söz konusu TİS'in temsil kabiliyetinin olduğu kabul edilmektedir. Ancak, mevcut TİS kapsamı istatistikleri, dikkate alınan tek koşul değildir. Genişletme kararı veren üçlü yapıdan oluşan kurul aynı zamanda, TİS'in kendi sektöründe nasıl bağıtlandığını ve pazarlık biriminde 
örgütlü işveren ve çalışanların yüzdesini de dikkate almaktadır (Malmberg, 2002: 207; Eurofound, 2011: 5; Bayc1k, 2019: 20).

Bir diğer örnek İtalya'da, TİS'lerin otomatik olarak bütün çalışanlar açısından bağlayıcı hale gelmesi için, toplu pazarlık tarafı sendikaların en az \%50+1 temsil edilebilirlik eşiğine ulaşması ve referandum yoluyla işçiler tarafından onaylanması gerekmektedir. Ayrıca, işyerindeki üye çoğunluğunu veya çalışanlar tarafından seçilen üyelerin çoğunu alan işyeri düzeyindeki sendikal yapılar tarafından imzalanan TİS'ler, tüm işçiler için bağlayıcıdır (Eurofound, 2015: 27). Almanya'da ise, 2015 yılına kadar, Toplu Pazarlık Komitesi'nin genişletmeyi oy çokluğu ile kabul etmesi durumunda, TİS sektördeki işçilerin en az \%50'sini kapsaması koşuluyla genişletilebilmekteydi. Ancak 2014'te çıkarılan Pazarlık Özerkliğinin Güçlendirilmesi Hakkında Kanun ile bu koşulun yerine, "kamu yararı" koşulu getirilmiştir. Bunun için önemli kriterlerden biri de, fiili kapsama oranını hesaba katan TİS'in “ön baskınlık önemi”dir (Müller ve Schulten, 2019: 246). Hollanda' da genişletme için asgari şart ise, TİS'in ilgili çalışanların en az \%55'ini kapsamasıdır (Villanueva, 2015: 2; Eurofound, 2011: 8). Diğer taraftan Hollanda'da TİS’leri gönüllü olarak uygulayan bazı şirketler de vardır, ancak bu kapsamlı bir uygulama değildir. Ayrıca TİS kapsamındaki bir işveren sendikalı olmasa bile, çalışanlara sendika üyeleriyle aynı şartları sunmakla yükümlüdür (Eurofound, 2011: 9).

Kullanım sıklığı açısından ise, Belçika, Finlandiya, Fransa, 2011'e kadar Yunanistan, Lüksemburg, Hollanda, 2012'ye kadar Portekiz, İspanya'da genişletme uygulaması oldukça yaygındır. Ayrıca Avusturya, İrlanda (2009-2011), İtalya, 2008'e kadar Slovenya ve 2011'e kadar Romanya'da fonksiyonel eşitlik nedeniyle genişleme oldukça yaygın bir uygulamadır. Ancak, yukarıda bahsedildiği gibi, genişletme mekanizmasına oldukça sık başvuran ülkelerde, işverenlerin örgütlenme yoğunluğu, sendikal yoğunluktan çok daha yüksektir. Öte yandan, Hırvatistan, Bulgaristan, Çek Cumhuriyeti, Estonya, Almanya, Macaristan, İrlanda, Letonya, Litvanya, Norveç, Polonya, Slovakya ve Slovenya'da genişletme mümkün olmasına rağmen, ya nadiren kullanılmakta ya da hiç kullanılmamaktadır. Güney Kıbrıs, Danimarka, 2011 'den beri İrlanda, Malta, İsveç ve İngiltere'de ise, TİS'lerin yasal olarak genişletilmesi mümkün değildir (Eurofound, 2015: 27; Eurofound, 2011: 2-3). Ancak TİS'lerin sadece sendika üyeleri için yasal olarak bağlayıcı olduğu Bulgaristan, Almanya, Litvanya, İsveç ve İngiltere'de, uygulamada 
işverenler genellikle şirket içindeki tüm çalışanlar için aynı veya benzer koşulları sağlamaktadır (OECD, 2017: 141; Eurofound, 2015: 27).

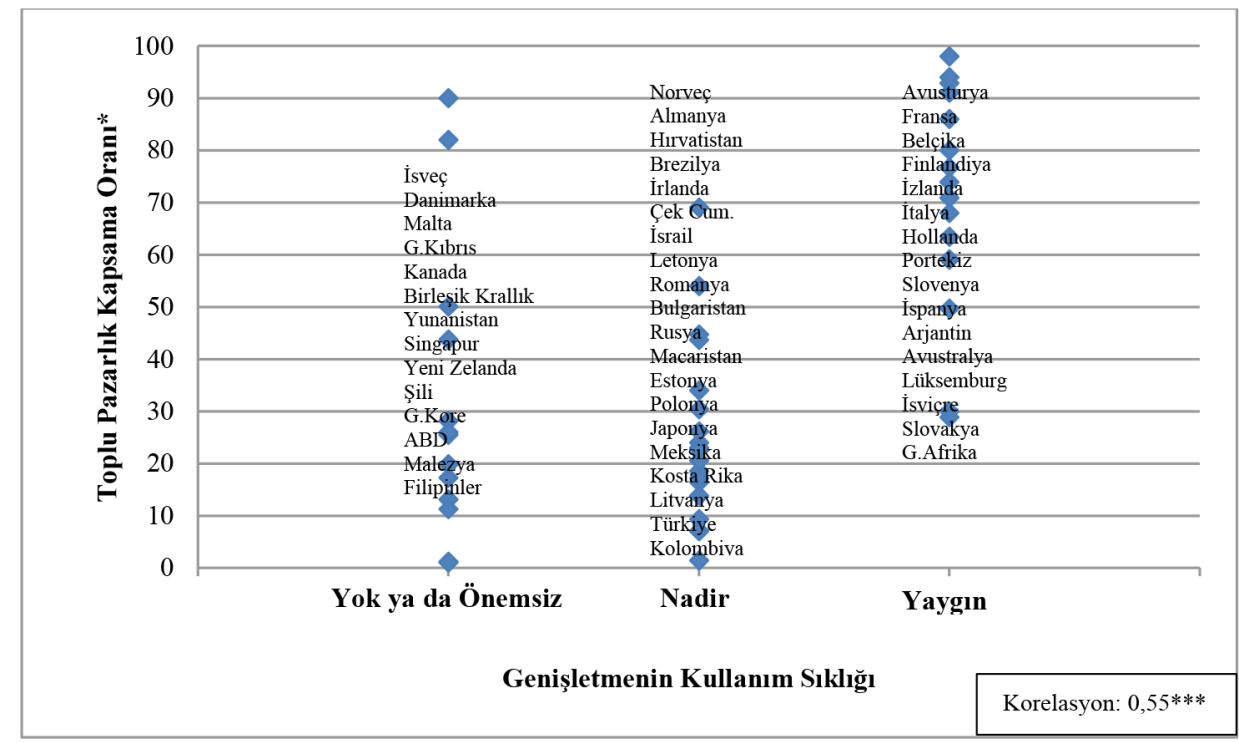

Grafik 6. Toplu pazarlık kapsama oranı ile genişletmenin kullanım sıklığı arasındaki ilişki *** 0,001 düzeyinde istatistiksel olarak anlamlı

Kaynak: OECD, 2017: 164; * Visser, (2019), ICTWSS Database Version 6.1

Not: Ülkeler toplu pazarlık kapsama oranı açısından yukarıdan aşağı sıralanmıştır.

Ülkelerin toplu pazarlık kapsama oranları ve genişletme mekanizmasının kullanım sıklı̆̆ı arasındaki korelasyon Grafik 6'da gösterilmektedir. Buna göre, toplu pazarlık kapsama oranı ile genişletme mekanizmasının kullanım sıklığı arasında doğrusal yönde orta düzeyli anlamlı $(\mathrm{r}=0,55$; $\mathrm{p}<$ 0,001) bir korelasyon bulunmaktadır. İsveç ve Danimarka gibi genişletme mekanizmasının kullanılmadığı ülkelerde ya da Norveç ve Almanya gibi nadiren kullanıldığı ülkelerde toplu pazarlık kapsama oranının yüksek olması, iki değişken arasındaki korelasyonu düşürmektedir.

\section{Türkiye'de Genişletme Mekanizması}

Türkiye'de endüstri ilişkileri sistemini düzenleyen kanunlarda, 1963’ten günümüze ilkesel olarak, TİS'lerin sadece pazarlık tarafları ve onların temsil ettiği üyeleri için geçerli olduğu ikili bağl1lık kuralı kabul edilmiştir. Bu ilkeye bağlı olarak, sendika üyesi olmayan çalışanların imzalanan TİS'den yararlanmaları ise, sendikalara finansal güvence sağlayan dayanışma aidatı ödemeleri koşuluna bağlanmıştır. 
Türkiye'de genişletme mekanizması, sendikal temsil yetkisindeki değişikliklere bağlı olarak, 1963’ten günümüze Türk endüstri ilişkileri sisteminde düzenlene gelmiştir. Genişletme için aranan minimum şartlar açısından, 275 sayılı Kanun döneminde, TİS'in aynı işkolundaki diğer işçilere ve işverenlere genişletilmesi, TİS kapsamındaki işçilerin, işkolunda çalışan işçilerin çoğunluğunu temsil etmesi koşuluna bağlanmış, ancak 1980'de çıkarılan 2364 sayılı Kanun ile işkolunda çoğunluk temsili şartı kaldırılmıştır (Subaşı, 2013: 211). 1983 sonrası 2822 sayılı Kanun döneminde bu koşul, genişletilecek TİS'in işkolunda çalışan işçilerin en az \%10'unu temsil eden sendikalardan en çok üyesi olan sendika tarafından bağıtlanması, olarak değiştirilmiştir. En son 6356 sayılı Kanun döneminde ise, genişletme için gerekli şartlardan işkolu barajı şartı kaldırılarak, genişletmeleri sadeleştirmek ve teşvik etmek amacıyla, TÍS'in işkolunda en çok üyeye sahip sendika tarafından bağıtlanmış olması koşulu getirilmiştir (Dereli, 2013: 59; Subaş1, 2013: 223).

Türkiye' de genişletme prosedürünü başlatma inisiyatifi, 275 sayılı Kanun döneminde, herhangi bir tarafın talebine bağlı olmaksızın başlatılıyorken, 1980'den itibaren, 6356 sayılı Kanun döneminde de, genişletme prosedürü işkolundaki işçi veya işveren sendikaları veya ilgili işverenlerden birinin veya Çalışma Bakanı'nın talebi ile başlatılmaktadır. 275 sayılı Kanun döneminde, bir işkolunda gerekli asgari koşulu sağlayan TíS'ler, Yüksek Hakem Kurulu'ndan görüş alındıktan sonra, (1980'den sonra tamamen veya kısmen veya zorunlu değişiklikler yapılarak) Bakanlar Kurulu tarafından genişletiliyorken, 2017 Anayasa değişikliği sonrası, bu yetki Cumhurbaşkanı'na geçmiştir.

Türkiye'de endüstri ilişkileri sisteminin kurumsallaştığı 1963’ten beri, ilgili kanunlarda genişletme mekanizması düzenlenmesine rağmen, 19631980 döneminde getirilen ağır koşul nedeniyle hiç uygulanamamış (Subaşı, 2013: 223), grev ve lokavt yasağının bulunduğu 1980-1983 döneminde 63 kez, 2822 sayılı Kanun döneminde ise, sadece 18 kez kullanılarak (Subaşı, 2013: 234; Baycık, 2019: 41), etkisi oldukça sınırlı kalmıştır (Çelik, 2019: 55). 6356 sayılı Kanun döneminde henüz kullanılmayan genişletme mekanizması, endüstri ilişkileri sisteminde, toplu pazarlık kapsamını yükseltmesi açısından, beklenen sonucu verememiştir. 


\section{Sonuç}

Bu çalışmada, toplu pazarlık kapsamını etkileyen faktörler ile toplu pazarlık kapsamı arasındaki ilişki, korelasyon analizi ve karşılaştırmalı endüstri ilişkileri yöntemleri ile açıklanmaya çalışılmıştır. Çalışmanın ulaştığı kritik sonuçlar şu şekilde şöyle özetlenebilir:

- Toplu pazarlık kapsama oranı ile sendikal yoğunluk, toplu pazarlık koordinasyon derecesi ve genişletme mekanizmasının kullanım sıklığı arasında orta düzeyli bir korelasyon gözlenirken, toplu pazarlık kapsama oranı ile işveren örgütlenme yoğunluğu ve baskın toplu pazarlık düzeyi arasında yüksek düzeyli bir korelasyon bulunmaktadır.

- Toplu pazarlık kapsamı yüksek olan ülkeler incelendiğinde, temel olarak yüksek sendikal yoğunluğun, merkezi düzeyli toplu pazarlıkların ve genişletme mekanizmalarının sık kullanımının toplu pazarlık kapsamını yükselten değişkenler olduğu görülmüştür. Ancak sendikal yoğunluğun artmas1, İskandinav ülkelerinde olduğu gibi, bir gent sisteminin varlığına ihtiyaç duyarken, merkezi düzeyli toplu pazarlıklar ve genişletme mekanizmalarının sık kullanımı yüksek işveren örgütlenme yoğunluğuna bağlıdır.

- Karşılaştırma yapılan ülkelerde toplu pazarlık temsil yetkisi kriterleri olarak, belirli bir sayıda üyeye sahip olma, yasal düzenleme, sosyal taraflar arası anlaşma, çalışanların katıldığı seçimde belirli bir oy düzeyine ulaşma ve yargı kararları ile oluşturuluyorken, Türkiye'de toplu pazarlık temsil yetkisi kanunla belirlenen ve sendika üye sayısına bağlı işkolu barajının yanı sıra, işyeri ve işletme barajlarından oluşmaktadır. Türkiye'de toplu pazarlık temsil yetkisinin ikili baraj kriterine bağlanması, uygulamada özellikle yeni kurulan sendikaların temsil yetkisi almalarını zorlaştırarak, toplu pazarlık kapsamının düşmesine yol açmaktadır.

- 2012 sonrası dönemde, Türkiye'de sendikaların toplu pazarlıkta temsil yetkisi alabilmeleri için gereken işkolu ve işletme barajları düşürülmesine rağmen, toplu pazarlık kapsama oranları, hem sendikal yoğunluktan, hem de işverenlerin örgütlenme yoğunluğundan (ICTWSS verisi \%18, OECD verisi \%20-30) daha düşüktür ve bu negatif fark her yıl artarak devam etmektedir. $\mathrm{Bu}$ durum, çalışanların bir kısmının, sendika üyesi olmalarına rağmen, toplu pazarlık kapsamına giremedikleri ve aslında örgütlenme haklarını kullanırken, bir takım engellerle karşılaştıkları anlamına gelmektedir. 
- Toplu pazarlık kapsamının görece yüksek olduğu ülkelerde sektörel ve ulusal düzeyde toplu pazarlıkların baskın olduğu gözlenirken, Türkiye'de baskın toplu pazarlık düzeyi işyeri ve işletme düzeyidir. Ayrıca, Türkiye'de hukuki olarak sektörel düzeyde toplu pazarlık yapmak mümkün olmamakla birlikte, sektörel toplu pazarlığın yerine grup toplu pazarlığı geleneği bulunmaktadır.

- Türkiye'de ikili bağlılık kuralı gereği, toplu pazarlık yoluyla belirlenen ücret ve çalışma koşullarından sadece imzacı toplu pazarlık tarafları ve üyeleri faydalanmaktadır, yani erga omnes kuralı yoktur. Ancak, sendika üyesi olmayan çalışanları da dayanışma aidatı ödeyerek TİS'den yararlanması mümkündür.

- Türkiye'de endüstri ilişkilerinin kurumsallaştı̆ğ dönemden itibaren, TİS'lerin genişletilmesi yasal olarak düzenlenmesine rağmen, uygulamasının oldukça nadir olması nedeniyle, toplu pazarlık kapsamında belirgin bir artış oluşturamamıştır.

\section{Türk Endüstri İlişkileri Sisteminin Modernizasyonu için Model Önerileri}

Türkiye'de toplu pazarlık yapısı ve kapsamına yönelik yapılan yukarıdaki tespitlerin, endüstri ilişkilerinin kurumsallaştığ dönemden günümüze süre gelen Türkiye'nin ekonomik, sosyal ve siyasi kriz ve sorunlarından kaynaklandığı söylenebilir. Bu yüzden, Türkiye'de toplu pazarlık kapsamının artırılması için sosyal tarafların da sürece dahil edildiği, uzun vadeli hukuki ve idari reformlarla endüstri ilişkileri sisteminin çağın gereklerine uydurulması, yani aktörlerden örgütlenme özgürlüğü ve toplu pazarlı̆̆ın yapısına kadar her alanda modernize edilmesi gerekmektedir. Öncelikle demokratik kitle örgütü olan sendikaların çoğulculuk, şeffaflık, açıklık, katılımcılık ve hoşgörü gibi demokratik ilkeleri içselleştirip, bütün çalışan temsilcilerinin seçimle belirlenmesinin yanı sıra, TİS oylaması gibi yenilikleri gelenek haline getirmesi gerekmektedir. Diğer taraftan, ulaşılan bulgular çerçevesinde, diğer ülke uygulamaları temelinde, Türkiye'de endüstri ilişkileri sisteminin modernizasyonu için öneri varyasyonları aşağıda değerlendirilmiştir.

Türkiye'de, özellikle yeni kurulan sendikaların, işkolu barajı nedeniyle toplu pazarlık temsil yetkisi alamamaları, endüstri ilişkilerinin en temel sorunlarından biri olup, Türkiye'deki sendikaların \%70'ini toplu pazarlık 
faaliyetinin dişında bırakmaktadır. Bu sorun ILO tarafından da sürekli dile getirilmekle birlikte, işkolu barajının kaldırılması ya da işkolu barajını aştığı halde, işyeri veya işletme barajına takılan sendikalara, en azından kendi üyeleri adına, toplu pazarlık yapma hakkının tanınması talep edilmektedir. Ancak, Türkiye'de işkolu barajının kaldırılması hem sosyal tarafların bu nokta uzlaşması, hem de sendikal gücün bölünmemesi açısından kısa vadede oldukça zor gözükürken, işyeri veya işletme barajını aşamayan sendikalara kendi üyelerine münhasır toplu pazarlık yapma hakkının verilmesi hem tek toplu pazarlık ilkesi, hem de işverenin çalışanlarına eşit davranma borcu açısından kabul edilebilir gözükmemektedir.

Toplu pazarlıkların çalışan haklarını gerçek manada koruyup geliştirmesi, sendikal çoğulculuk, sendikalar arası rekabet ve toplu pazarlık biriminde temsil yetkisinin temsil gücü en yüksek sendikaya verilmesi yoluyla gerçekleştirilebilir. Temsil gücü açısından, toplu pazarlık tarafi olan sendikanın, Almanya'da olduğu gibi, işvereni toplu pazarlık masasına oturtma ve imzalanan TİS'i uygulatma yeterliliğinin ve gücünün olması son derece önemlidir. Bu yüzden, toplu pazarlık temsil yetkisi açısından belirli üye yoğunluğuna ulaşamamış sendikalara toplu pazarlık yetkisinin verilmesi, temsil gücü ve toplu pazarlıkların çalışanların ücret ve çalışma koşullarını gerçek manada iyileştirmesi anlayışına uygun değildir. $\mathrm{Bu}$ kapsamda, Türkiye'nin hiçte yabancı olmadığı aynı işkolundaki sendikaların federasyon tipi üst örgütlenmesinin önünü açılarak, bu sendikaların işkolu barajını aşmaları sağlanabilir. Diğer taraftan, işyeri ve işletme barajları yerine, işyerinde ya da işletmede "üye çoğunluğu” koşulu getirilerek, federasyon üyeliği ile işkolu barajını aşan ve işyeri ya da işletmede en çok üyeye sahip olan sendikanın toplu pazarlık temsil yetkisinin olduğu kabul edilmelidir. Ayrıca temsil yetkisinin ve itirazların değerlendirilmesi Bakanlık yerine, mahkeme yolu açık olmak üzere, üçlü bir yapıdan oluşan bağımsız bir kuruma bırakılmalıdır. Böylece, temsil yetkisinin bağımsız bir kurum tarafindan verilmesinin yanı sıra, federasyon tipi üst örgütlenme modeli ile hem işkolu barajı anlamında temsil gücü, hem de toplu pazarlıkların federasyonlar yoluyla koordine edilmesi yoluyla çalışanların ücret ve çalışma koşullarında daha fazla iyileşme sağlanabilir. Örneğin, Japonya' da çoğu işyeri sendikası, örgütlenme, toplu pazarlık ve grev hakkı bulunmayan ve görevi tamamen sektörel düzeyde çalışma koşullarıyla ilgili taleplerin birleştirilmesi ve toplu pazarlıkların koordine edilmesi olan sektör düzeyindeki gevşek federasyonlara üye olmaktadır (Oh, 2006: 12-13). 
Bu örneğin Türkiye'ye uyarlanması ile işkolu barajını aşamayan sendikaların temsil yetkisi tespitinde bağlı olduğu federasyonun işkolu barajı dikkate alınarak, hem tek toplu pazarlık ilkesi korunabilir, hem de sendikalarının işkolu barajını aşmaları sağlanabilir. Bununla birlikte, toplu pazarlıkta temsil yetkisi sendikada olmakla birlikte, federasyonların danışmanlık, mali ve teknik desteğinde toplu pazarlığın koordinasyonu ile hem sendikaların toplu pazarlık güçleri artabilir, hem de ikili bağlılık kuralı yerine işverenin çalışanlarına eşit davranması kapsamında erga omnes kuralı getirilerek, imzalanan TİS'lerden toplu pazarlık birimindeki tüm çalışanların faydalanması sağlanabilir.

Diğer alternatif varyasyon, sektörel ve işyeri/işletme toplu pazarlıklarının aynı anda uygulandığı çok düzeyli toplu pazarlıların önünün açılmasıdır. $\mathrm{Bu}$ varyasyonda, federasyonlara işkolu düzeyinde daha alt düzeyli TíS'lerin genel çerçevesini ve alt-üst limitleri belirleyen gevşek TíS bağıtlama yetkisi verilebilir. Örneğin Fransa, Portekiz ve İspanya'da, şirket düzeyindeki TİS'ler ve sektör düzeyindeki TİS'lerle bir arada bulunabilmektedir. Portekiz'de, çalışanların \%73'ü bir toplu pazarlık kapsamındayken, çalışanların sadece \%10'u şirket düzeyinde toplu pazarlık kapsamındadır (Villanueva, 2015: 2). Ancak bu ülkelerde işveren örgütlenme yoğunluğunun görece çok yüksek olduğu unutulmamalıdır. İşveren örgütlenme yoğunluğunun artması koşuluyla, Türkiye'de çok düzeyli toplu pazarlığa geçilmesi önerilebilir. Ancak Türkiye'de zaten grup toplu pazarlıkların işkolu toplu pazarlığı işlevi gördüğü öne sürülebilir. Fakat Türkiye'de uygulanan grup toplu pazarlığ1, yapı itibariyle işkolu toplu pazarlığına benzese de, gerek toplu pazarlık birimi, gerekse müzakerelerin birden fazla sendika ile yürütülmesi yönüyle, işkolu toplu pazarlı̆̆ından ayrılmaktadır. Yani, grup toplu pazarlığını birçok ülkede uygulanmakta olan sektörel düzeydeki toplu pazarlıkların ikamesi gibi görmek doğru değildir (Baycık, 2019: 10). Son y1llarda Almanya ve Hollanda gibi ülkelerde kontrollü adem-i merkeziyetçilik kapsamında yaygın bir uygulama haline gelen sektörel TİS'lere genel açık hükümler ve geçici sapma hükümlerinin konması, Türkiye'de işkolu ve işyeri/işletme düzeyindeki TİS'lerin birlikte uygulanmasını kolaylaştırabilir (Baycık, 2019: 12). Ayrıca, Avrupa ülkelerinde olduğu gibi, belirli bir temsil eşiğinin aşan toplu pazarlık taraflarının imzaladığı, en azından ücret ve çalışma koşullarının genel çerçevesinin belirlendiği sektör düzeyindeki toplu pazarlıklar için erga omnes kuralı getirilerek, otomatik ya da yarı otomatik genişletme mekanizmaları yoluyla sendika üyesi olmayan çalışanlar da toplu pazarlık kapsamına 
alınabilir.

Son olarak, Baycık’ın (2019) hazırladığı raporda, genel açık hükümler veya geçici sapma hükümleri ile işverenlere çeşitli esneklikler sağlanarak, işkolu düzeyinde toplu pazarlıklar yoluyla toplu pazarlık kapsamının artırılabileceği ve ardından toplu pazarlıkların genişletilmesinin yaygınlaştırılması önerilmektedir. Ancak, Türkiye'de genişletme mekanizmasının etkin kullanımın önündeki en büyük engeller sadece işyeri ve işletme düzeyindeki toplu pazarlıkların baskınlığı değil, aynı zamanda düşük sendikal yoğunluk ve işveren örgütlenme yoğunluğu ile TİS'lerde ikili bağlılık kuralının uygulanmasıdır. Bu yüzden, Türkiye'de öncelikle toplu pazarlık düzeyinin yükseltilmesi ve daha sonra genişletme mekanizmaları yoluyla toplu pazarlık kapsamının artırılması uygulanabilir bir yaklaşım değildir. $\mathrm{Bu}$ anlamda, Türkiye'de temel olarak işveren örgütlenme yoğunluğu artmadan, çok düzeyli toplu pazarlık yapısına geçilmesi ya da genişletme mekanizmaları yoluyla toplu pazarlık kapsamının artırılması oldukça güç gözükmektedir. Bu yüzden, bu yaklaşım, öncelikle genişletme mekanizmasının sık kullanımı ile işveren örgütlenme yoğunluğunun artmasına bağlı olarak, daha sonra işkolu düzeyinde toplu pazarlıklara geçilmesi halinde başarılı olabilir. Çünkü Fransa ve Finlandiya örneklerinde olduğu gibi, genişletme mekanizmasının kullanımı işverenlerin örgütlenme eğilimlerinin artıran bir etki oluşturabilir ve ardından işveren örgütlenme yoğunluğunun artması da işkolu düzeyinde toplu pazarlığa geçişi ve bu modelin başarılı bir şekilde uygulanmasını kolaylaştırabilir.

Peer-review: Externally peer-reviewed.

Conflict of Interest: The author has no conflict of interest to declare.

Grant Support: The author declared that this study has received no financial support. 


\section{Kaynakça/References}

AÇSHB. (2020). Sendikal İstatistikler. Ocak 2013-Ocak 2020.

AÇSHB. (2017). Yıllar İtibarıyla İmzalanan Toplu İş Sözleşmeleri 1984-2017.

Bamber, G. J., Lansbury, R. D., \& Wailes, N. (2004). Introduction, Chapter 1, In: International and Comparative Employment Relations: Globalisation and the Developed Market Economies, (Eds. Bamber, G. J., Lansbury, R. D. and Wailes, N.), $4^{\text {th }}$ Edition, Allen \& Unwin, Crows Nest, Australia.

Baycık, G. (2019). Avrupa Birliği Üye Devletlerinde Teşmil Uygulaması ve Türkiye için Öneriler. 'Çalışma Hayatında Sosyal Diyaloğun Geliştirilmesi' Projesi kapsamında, (ILO) Türkiye Ofisi, Ankara.

Black, B. (2005). Comparative industrial relations theory: the role of national culture. The International Journal of Human Resource Management, 16(7), 1137-1158, DOI:10.1080/09585190500143980.

Blanpain, R. (1982). Comparativism in Labour Law and Industrial Relations. Chapter 1. In: Comparative Labour Law and Industrial Relations (Eds. Blanpain, R. and Millard, F.), $1^{\text {st }}$ Edition, Netherlands.

Colson, A., Elgoibar, P., \& Marchi, F. (2014). Employee representatives in France: employers' perceptions and expectations towards improved industrial relations. Research Center ESSEC, Working Paper: 1407.

Çelik, A. ve Lordoğlu, K. (2006). Türkiye'de resmi sendikalaşma istatistiklerinin sorunları üstüne. Çalışma ve Toplum Dergisi, (9), 11-30.

Çelik, A. (2019). Sembiyotik ilişkiler ve otoriter korporatizm kıskacında 2010'lu yıllarda Türkiye'de sendikalaşma, toplu pazarlık ve grev eğilimleri. Uluslararası Yönetim Iktisat ve İsletme Dergisi, ÇEEİK 2018 Özel Sayısı, 39-69.

Dereli, T. (2009). Endüstri ilişkileri ve çalışma hukuku alanında karşılaştırmalı araştırmalar ve yöntem. Sosyal Siyaset Konferansları Dergisi, 56, 1-20.

Dereli, T. (2013). 6356 sayılı yeni sendikalar ve toplu iş sözleşmesi kanunu: Genel bir değerlendirme. Çalışma ve Toplum Dergisi, (36), 41-64.

DİSK. (2019). DISK-AR Sendikalaşma Araştırması, Türkiye’de Sendikalaşma, Toplu İ̧̧ Sözleşmesi Kapsamı ve Grevler. (2013-2019).

Engin, M. (2013). 6356 sayılı yasa'da toplu iş sözleşmesi yetkisi. Çalışma ve Toplum Dergisi, (39), 143-163.

Eurofound. (2015). Collective Bargaining in Europe in the 21st Century. Publications Office of the European Union, Luxembourg.

Eurofound. (2011). Extension of collective bargaining agreements in the EU. Background Paper, 1-12.

Eurofound. (2019). Trade Union Density, European Industrial Relations Dictionary. Erişim adresi: https://www.eurofound.europa.eu/observatories/eurwork/industrialrelations-dictionary/trade-union-density. 
Görmüş, A. (2012). Türkiye'de toplu pazarlık düzeyleri ve yeni gelişmeler. Balkan Sosyal Bilimler Dergisi, 1(2), 32-48.

Görmüş, A. (2018). Endüstri Illişkileri Sistemlerinin Karşılaştırmalı Analizi: Benzeşme ve Farklılaşma Alanları. Kocaeli: Umuttepe Yayınları.

Hayter, S., \& Stoevska, V. (2009). Social dialogue indicators trade union density and collective bargaining coverage. ILO Technical Brief, International Statistical Inquiry 2008-09, 1-15.

Høgedahl, L. K., \& Kongshøj, K. (2017). New trajectories of unionization in the nordic ghent countries: Changing labour market and welfare institutions. European Journal of Industrial Relations, 23(4), 365-380, https:/doi.org/10.1177/0959680116687666.

ILO. (2018). Quick Guide on Sources And Uses of Collective Bargaining Statistics. ILO Publications, International Labour Office, Geneva, Switzerland.

ILO. (2019). ILO Uzmanlar Komitesi 2019 yılı Türkiye Raporu. Erişim adresi: https:// www.ilo.org/wcmsp5/groups/public/---europe/---ro-geneva/---ilo-ankara/documents/ meetingdocument/wcms_676283.pdf.

ILO. (2019). Örgütlenme Özgürlüğ̈̈, Örgütlenme Özgürlüğü Komitesi Kararlarl Derlemesi. (Çev. Ünlütürk Ulutaş, Ç.) Uluslararası Çalışma Bürosu- Cenevre: ILO, 6. Bask1.

Keune, M. (2010). Derogation Clauses on Wages in Sectoral Collective Agreements in Seven European Countries. Dublin: European Foundation for the Improvement of Living and Working Conditions.

Kochan, T. (1998). What is Distinctive about Industrial Relations Research? In: Researching the World of Work: Strategies and Methods in Studying Industrial Relations, (Eds. Whitfield, K. \& Strauss, G.) Ithaca, NY: Cornell University Press.

Kutal, M. (2014). Sendikalar ve toplu iş sözleşmesi yasasının kimi hükümlerinin iptali istemi. Çalışma ve Toplum Dergisi, (43), 13-28.

Lesch, H. (2004). Trade Union Density in International Comparison. CESifo Forum 4/2004: 12-18.

Locke, R., Kochan, T., \& Piore, M. (1995). Reconceptualizing comparative industrial relations: Lessons from international research. International Labour Review, 134(2), 139-161.

Mahiroğulları, A. (2001). Türkiye'de 1980 sonrası sendikalaşma ve sendikalaşmayı etkileyen unsurlar. I.U. iktisat Fakültesi Maliye Araştırma Merkezi Konferansları, 123-144.

Mahiroğulları, A. (2020). Dünyada ve Türkiye’de Sendikacılık. Ekin Yayınevi, 4. Baskı, Bursa.

Malmberg, J. (2002). The Collective Agreement as an Instrument for Regulation of Wages and Employment Conditions. Stockholm Institute for Scandinavian Law 1957-2009, 189-213, Erişim adresi: www.scandinavianlaw.se/ pdf/43-7.pdf. 
Molina, O. (2019). Working Life in Spain. In: European Foundation for the Improvement of Living and Working Conditions, Erişim adresi: https://www.eurofound.europa.eu/tr/ country/spain.

Mouret, J. (2007). Collective Relations in France: a Multi-layered System in Mutation". In: Decentralizing Industrial Relations and the Role of Labour Unions and Employee Representatives, (Ed. Blanpain, R.) La Haye, Kluwer Law International.

Müller, T. and Schulten, T. (2019). Germany: Parallel Universes of Collective Bargaining. Chapter 12, In: Collective Bargaining in Europe: towards an Endgame, Volume II, (Eds. Müller, T., Vandaele, K. and Waddington, J.), ETUI aisbl, Brussels.

OECD Stat, Trade Unions and Collective Bargaining 2015-2018, Erişim adresi: https://stats.oecd.org/.

OECD. (2017). OECD Employment Outlook 2017. OECD Publishing, Paris, http://dx.doi.org/10.1787/empl_outlook-2017-en

Oesingmann, K. (2016). The extension of collective agreements in Europe. Dice Report, Munich, 14(2), 59-64.

Oh, H. S. (2006). Collective Bargaining in Japan, Report on the Survey on Industrial Relations in East Asia. ILO-Japan Multi-Lateral Project.

Özveri, M. (2012). Sendikal Haklar 6356 Sayılı Sendikalar ve Toplu İş Sözleşmesi Yasası. İstanbul: Birleşik Metal-İş Yayınları.

Özveri, M. (2013). Türkiye’de Toplu İş Sözleşmesi Yetki Sistemi ve Sendikasızlaştırma (1963-2009). Ankara: Ankara Üniversitesi Siyasal Bilgiler Fakültesi Yayınları.

Pedersini, R. (2019). Working Life in Italy. In: European Foundation for the Improvement of Living and Working Conditions, Erişim adresi: https:/www.eurofound.europa.eu/tr/ country/italy.

Scheuer, S. (1997). Collective bargaining coverage under trade unionism: A sociological investigation. British Journal of Industrial Relations, 35(1), 65-86.

Subaşı, İ. (2013). 6356 sayılı sendikalar ve toplu iş sözleşmesi kanununda toplu iş sözleşmesi teşmili. Çalışma ve Toplum Dergisi, (39), 209-246.

Sungur, O. (2014). Korelasyon Analizi. İçinde: SPSS Uygulamalı Çok Değişkenli İstatistik Teknikleri, (Ed. Kalaycı Ş.), 6. Baskı, Ankara: Asil Yayın Dağıtım.

Sur, M. (2013). 6356 sayılı kanununun uluslararası normlar açısından değerlendirilmesi. Çalışma ve Toplum Dergisi, (39), 317-356.

Traxler, F. (1998). Collective bargaining in the OECD: developments, preconditions and effects. European Journal of Industrial Relations, 4(2), 207-226.

Traxler, F. (1994). Collective Bargaining: Levels and Coverage, Chapter 5, In: OECD Employment Outlook, 167-94.

Ulber, D. (2011). Neues zur Tariffaehigkeit. RdA 2011, Heft 6, 353. 
Van Oycke, J., Van Gyes, G., \& Van Herreweghe, D. (2019). Working Life in Belgium. In: European Foundation for the Improvement of Living and Working Conditions, Erişim adresi: https://www.eurofound.europa.eu/tr/country/belgium.

Villanueva, E. (2015). Employment and Wage Effects of Extending Collective Bargaining Agreements. IZA World of Labor 136, 1-10, doi: 10.15185/izawol.136.

Vincent, C. (2019). France: the Rush towards Prioritising the Enterprise Level, Chapter 11, In: Collective Bargaining in Europe: towards an Endgame, Volume II, (Eds. Müller, T., Vandaele, K. and Waddington, J.), ETUI aisbl, Brussels.

Visser, J. (2019). ICTWSS Database Version 6.1. Amsterdam: Amsterdam Institute for Advanced Labour Studies (AIAS), University of Amsterdam.

Visser, J., Hayter, S. and Gammarano, R. (2017). Trends in Collective Bargaining Coverage: Stability, Erosion or Decline?, ILO, Labour Relations and Collective Bargaining, ISSUE BRIEF No.1, 1-12.

Whitfield, K., Delbridge, R., \& Brown, W. (1999). Comparative research in industrial relations: Helping the survey cross frontiers. International Journal of Human Resource Management, 10(6), 971-980. DOI: 10.1080/095851999340062.

Yorgun, S. (2013). Sosyal politika açısından 6356 sayılı sendikalar ve toplu iş sözleşmesi kanunu. Çalışma ve Toplum Dergisi, (43), 357-380.

Zaim, S. (1997). Çalışma Ekonomisi (10. Bask1), İstanbul: Filiz Kitabevi. 
